\title{
FAMILY VIOLENCE, CROSS-EXAMINATION AND SELF- REPRESENTED PARTIES IN THE COURTROOM: THE DIFFERENCES, GAPS AND DEFICIENCIES
}

\author{
TRACEY BOOTH, ${ }^{*}$ MIRANDA KAYE ${ }^{* *}$ AND JANE WANGMANN***
}

\begin{abstract}
Since the early 2000s, the ability of a self-represented litigant alleged to have used domestic and family violence including sexual violence to personally cross-examine the alleged victim of that violence has been steadily restricted or prohibited across the Australian jurisdictions. These statutory limitations recognise the traumatic and negative impact such personal cross-examination can have on the alleged victim. All Australian jurisdictions restrict such personal cross-examination in sexual offence proceedings. Many jurisdictions also impose similar limitations in proceedings for other domestic and family violence related criminal proceedings and civil protection order proceedings. This article reveals a marked unevenness in protection for alleged victims both across and within jurisdictions. The lack of consistency in approach and lack of uniformity in provisions across the jurisdictions means that not all victims of domestic and family violence are protected, and for those who are, the nature and extent of those protections differ.
\end{abstract}

\section{INTRODUCTION}

Since the early 2000 s, the ability of a self-represented litigant ('SRL') ${ }^{1}$ who is alleged to have used domestic and family violence including sexual violence to personally cross-examine the alleged victim of that violence has been steadily

\footnotetext{
* Associate Professor, Faculty of Law, University of Technology Sydney.

** Senior Lecturer, Faculty of Law, University of Technology Sydney.

*** Senior Lecturer, Faculty of Law, University of Technology Sydney. The authors are all members of the Law Health Justice Centre, UTS. They would like to thank Grace Stals and Alison Whittaker for their invaluable research assistance.

1 There is an array of different terms used for self-represented litigants (for example, 'pro se' in the USA; 'litigant in person' in England and Wales; and 'SRL' in New Zealand and Canada). In Australia, 'SRL' tends to be the current preferred term; although some scholars draw distinctions between people who are without representation through choice ('SRL') rather than circumstances, largely financial ('unrepresented'): E Richardson, T Sourdin and N Wallace, 'Self-Represented Litigants: Literature Review' (Literature Review, Australian Centre for Court and Justice System Innovation, Monash University, 24 May 2012) 10 [1.4].
} 
limited across the Australian jurisdictions. In 2003, New South Wales ('NSW') was the first jurisdiction to prevent a self-represented defendant from directly cross-examining the complainant in sexual offence proceedings. ${ }^{2}$ Every Australian jurisdiction has since followed suit in sexual offence proceedings, with many jurisdictions also imposing similar limitations in proceedings for other domestic and family violence related criminal offences, ${ }^{3}$ and in civil protection order proceedings. These statutory limitations were introduced in recognition of the traumatic and negative impact such personal cross-examination can have on the alleged victim, most of whom are women. ${ }^{4}$ However, the approaches adopted by state and territory legislatures vary markedly particularly in relation to whether the limitation is mandatory or discretionary, and the mechanism put in place to replace direct personal cross-examination.

The absence of a uniform approach across state and territory criminal and civil protection order proceedings highlights a number of tensions that underpin procedural reform to address domestic and family violence. First, there is the obvious tension between the rights of the accused/defendant to a fair hearing and the rights of an alleged victim of violence to also have a fair hearing that reduces their potential distress and humiliation in giving evidence and having it tested. ${ }^{5}$ There is a disjuncture between the concerns and interests of victims of domestic and family violence on the one hand and those of adversarial legal processes on

2 Criminal Procedure Act 1986 (NSW) s 294A. This provision was inserted in 2003 by the Criminal Procedure Amendment (Sexual Offence Evidence) Act 2003 (NSW).

3 In this article, we use the term domestic and family violence, however, when discussing a particular jurisdiction we use the term that is relied on in that jurisdiction (domestic violence, family violence, or domestic and family violence). Regardless of the term used, all jurisdictions define the relationships broadly (it includes not only intimate partner relationships, but other familial and close relationships). In this article we are primarily focusing on intimate partner relationships as this represents the vast majority of domestic violence cases that proceed at a criminal and civil level: see, eg, Victorian data available on the Crime Statistics Agency website for Family Violence Intervention Orders before the Magistrates' Court at 'Magistrates' Court', Crime Statistics Agency (Web Page, December 2018)

$<$ https://www.crimestatistics.vic.gov.au/family-violence-data-portal/family-violence-datadashboard/magistrates-court $>$; and Victoria Police data on recorded family incidents at 'Victoria Police', Crime Statistics Agency (Web Page, December 2018) < https://www.crimestatistics.vic.gov.au/familyviolence-data-portal/family-violence-data-dashboard/victoria-police $>$. We are interested in the protections afforded to adults as victims of domestic and family violence, rather than to children (who may have additional protections afforded to them because they are children) or adults who are identified as vulnerable as a result of a cognitive or other impairment.

4 This article refers to women as the main victims of domestic and family violence. This is in recognition that the vast majority of victims of domestic and family violence are women, and the majority of perpetrators are male: see Royal Commission into Family Violence: Report and Recommendations (March 2016) vol 1, 57-8; Australia's National Research Organisation for Women's Safety, Personal Safety Survey 2016: Fact Sheet (2017) <https://d2rn9gno7zhxqg.cloudfront.net/wpcontent/uploads/2019/01/19030553/ANROWS-PSS2016-Fact-Sheet-HR.pdf >; Katrina Grech and Melissa Burgess, 'Trends and Patterns in Domestic Violence Assaults: 2001-2010' (Issue Paper No 61, NSW Bureau of Crime Statistics and Research, May 2011) 6-7.

5 Law Council of Australia, Submission No 43 to Australian Law Reform Commission, Review of the Family Law System: Issues Paper 48 (7 May 2018) 12 [23] ('Review of the Family Law System'). 
the other. ${ }^{6}$ From a legal perspective, cross-examination is fundamental to a fair trial and prohibitions introduced to protect victims are seen by some to undermine the traditional rules of procedural justice. ${ }^{7}$ For many victims, however, direct and personal confrontation with the alleged perpetrator of violence in the courtroom is an extension of the violence and the legal proceedings become a site for further abuse rather than justice. ${ }^{8}$ Another obstacle to procedural reform is that domestic and family violence is framed differently by the different domains of legal practice - civil protection orders, criminal offences and family law - and as a result, victims and perpetrators are conceptualised and constructed differently for the purposes of each legal domain. ${ }^{9}$ This can affect how the person who has experienced the harm is positioned (as an alleged victim, a complainant, or as a parent) and hence how their 'claims' are conceptualised and understood in that doctrinal area.

The possibility of direct cross-examination of an alleged victim by a perpetrator of that violence is not only an issue in criminal and civil protection order proceedings, it is also an issue in family law proceedings. Up until this year there was only a discretionary provision to limit cross-examination in family law proceedings, but it was not specific to cases involving domestic and family violence and it was rarely used. ${ }^{10}$ As a result of increasing concern about this gap, the Attorney-General commissioned the Australian Institute of Family Studies to conduct research on the incidence and nature of direct cross-examination in family law matters in cases involving allegations of family violence to inform possible law reform. ${ }^{11}$ An Act came into force in March 2019 to prevent an alleged perpetrator of family violence being able to personally cross-examine the victim of that violence, and also prevent an alleged victim who is without legal representation personally cross-examining the perpetrator of that violence, in family law proceedings. ${ }^{12}$ To facilitate these protections the Federal Government

6 Tracey Booth, “"Cooling Out” Victims of Crime: Managing Victim Participation in the Sentencing Process in a Superior Sentencing Court' (2012) 45(2) Australian and New Zealand Journal of Criminology 214.

7 Phoebe Bowden, Terese Henning and David Plater, 'Balancing Fairness to Victims, Society and Defendants in the Cross-Examination of Vulnerable Witnesses: An Impossible Triangulation?' (2014) 37(3) Melbourne University Law Review 539.

8 Janet Loughman, 'Protecting Vulnerable Witnesses in Family Law' (2016) (19) Law Society of NSW Journal 26, 26. See also judicial recognition of the impact of direct cross-examination in Ewin v Vergara [No 3] (2013) 238 IR 118, 133 [63]-[64] (Bloomberg J).

9 This fragmented legal landscape was exposed clearly in Australian Law Reform Commission and New South Wales Law Reform Commission, Family Violence: A National Legal Response (ALRC Report No 114, NSWLRC Report No 128, October 2010) 139 [3.2]. See also Marianne Hester, 'The Three Planet Model: Towards an Understanding of Contradictions in Approaches to Women and Children's Safety in Contexts of Domestic Violence' (2011) 41(5) British Journal of Social Work 837; Julie Stubbs and Jane Wangmann, 'Competing Conceptions of Victims of Domestic Violence within Legal Processes' in Dean Wilson and Stuart Ross (eds), Crime, Victims and Policy: International Contexts, Local Experiences (Palgrave Macmillan, 2015) 107; Adrienne Barnett, "Like Gold Dust these Days": Domestic Violence Fact-Finding Hearings in Child Contact Cases' (2015) 23(1) Feminist Legal Studies 47, 50-1.

10 Family Law Act 1975 (Cth) s 69ZX(2)(i). This discretionary provision applies only to child-related proceedings.

11 Rachel Carson et al, Direct Cross-Examination in Family Law Matters: Incidence and Context of Direct Cross-Examination Involving Self-Represented Litigants (Report, 2018).

12 Family Law Amendment (Family Violence and Cross-Examination of Parties) Act 2018 (Cth). 
has funded the legal aid commissions to provide legal representation for the purposes of cross-examination in family law proceedings. ${ }^{13}$

It is commendable that the Federal Government has responded to this longrecognised problem. ${ }^{14}$ However, the fact that these new protections largely replicate some of the components of the approaches implemented in state and territory legislation in criminal and civil order proceedings is potentially problematic. Perhaps the most obvious difficulty is that family law proceedings are fundamentally different to criminal or civil protection order proceedings; this gives rise to questions about whether such provisions can simply be transposed from one legal arena to another. ${ }^{15}$ More problematic though, is the lack of evidence base to inform the model proposed for the family law context. To our knowledge, there has been no evaluation or assessment of the state and territory statutory models which could provide information about which approach is more effective and appropriate to reduce the trauma of direct personal cross-examination, whilst at the same time providing an alternative process that enables the SRL to test the evidence.

Given the movement at the federal level to introduce protections in the family law arena, it is timely to examine the current protections adopted by state and territory legislatures in civil protection order and criminal proceedings. This article analyses the different legislative models to protect adult victims ${ }^{16}$ of domestic and family violence against direct cross-examination by the alleged perpetrator of that violence across some of the legal processes that relate to domestic and family violence: criminal offences, including sexual offences, and civil protection orders. The article is divided into three parts. First, it explores the disjuncture between the

13 Kelly O’Dwyer and Christian Porter, 'New Funding for Family Law Services to Support Women to Recover Financially after Separation' (Media Release, Attorney-General's Department (Cth), 20 November 2018). For example in NSW, the scheme is administered by Legal Aid NSW and funding for legal representation under the scheme is at the current Legal Aid fee sale for the preparation and appearance at the final hearing: 'Family Cross Examination of Parties Scheme', Legal Aid New South Wales (Web Page) < https://www.legalaid.nsw.gov.au/for-lawyers/family-violence-and-crossexamination-of-parties-scheme $>$.

14 See Family Law Council, Litigants in Person: A Report to the Attorney-General Prepared by the Family Law Council (August 2000) 9 [1.24]; Family Court of Australia, Self-Represented Litigants: A Challenge (Report, 2003) 40; Productivity Commission, Access to Justice Arrangements (Inquiry Report No 72, 5 September 2014) 69 (Recommendation 24.2); Royal Commission into Family Violence: Report and Recommendations (n 4) vol 4, 197-8; Australian National Research Organisation for Women's Safety, Domestic and Family Violence and Parenting: Mixed Method Insights into Impact and Support Needs (Final Report, June 2017); Loughman (n 8).

15 Miranda Kaye, Jane Wangmann and Tracey Booth, 'Preventing Personal Cross-Examination of Parties in Family Law Proceedings Involving Family Violence’ (2017) 31(2) Australian Journal of Family Law 94, 113-15.

16 See above $\mathrm{n} 3$, the focus of this article is on adult victims of domestic and family violence. Our analysis therefore does not discuss provisions that protect witnesses with particular vulnerabilities (such as children or persons with cognitive impairment). For a discussion of protections for children or other vulnerable victims, see Annie Cossins, 'Cross-Examination in Child Sexual Assault Trials: Evidentiary Safeguard or an Opportunity to Confuse?' (2009) 33(1) Melbourne University Law Review 68; Bowden, Henning and Plater (n 7); Penny Cooper and Michelle Mattison, 'Intermediaries, Vulnerable People and the Quality of Evidence: An International Comparison of Three Versions of the English Intermediary Model' (2017) 21(4) The International Journal of Evidence and Proof 351. 
goals and interests of adversarial legal proceedings on the one hand and the concerns of victims of domestic and family violence on the other in order to contextualise the obstacles to legal solutions. This is followed by a detailed exploration of the various legislative protections in place across Australia to prevent direct cross-examination in criminal and civil protection order proceedings. In Part III we analyse the gaps and deficiencies in those statutory frameworks. While it is clear that the various limitations on direct crossexamination are intended to balance the needs and concerns of victims of violence with the accused's entitlements to a fair hearing, it is arguable that the lack of uniformity and unevenness in protection across Australian states and territories reflect an underlying resistance to changing traditional procedural rules.

\section{DISJUNCTURE BETWEEN THE LAW, ITS PROCESSES AND VICTIMS OF FAMILY VIOLENCE}

\section{A The Legal Perspective}

The tradition of orality is a distinctive feature of fact-finding in adversarial legal proceedings. Evidence is presented orally and tested by direct questioning of witnesses. Cross-examination is the process of questioning a witness called by the opposing party. In circumstances where a party intends to make a case that will contradict evidence given by a witness, the law requires the party to put their case to that witness in cross-examination. ${ }^{17}$ Failure to put the case in cross-examination means that the party cannot lead contradictory or discrediting evidence that they seek to rely on.

According to the New South Wales Law Reform Commission ('NSWLRC') in its 2003 report on direct cross-examination in sexual offence proceedings: 'It is a fundamental rule of natural justice that people on trial for criminal offences have the right to test the evidence against them ${ }^{18}$ In its submission to the Australian Law Reform Commission's ('ALRC') current review of the family law system, the Law Council of Australia emphasised the important role of cross-examination in fact finding:

If a party makes an allegation ... then it is a fundamental cornerstone of all adjudicative processes that the respondent thereto has a right to hear that allegation and have that allegation tested ... The testing often involves asking questions of both parties and any relevant witnesses. Once those questions are asked, it is then, and only then, that an allegation can be found as fact, or not. If the allegation is not tested, then a finding cannot be made. ${ }^{19}$

A key assumption underpinning cross-examination is that testing the credibility and the veracity of the witness by an 'intense and probing interrogation'

\footnotetext{
17 Known as the rule in Browne v Dunn (1893) 6 R 67.

18 New South Wales Law Reform Commission, Questioning of Complainants by Unrepresented Accused in Sexual Offence Trials (Report No 101, June 2003) 3 [1.7] ('Questioning of Complainants').

19 Review of the Family Law System (n 5) 12 [21]. See also Australian Law Reform Commission, New South Wales Law Reform Commission and Victorian Law Reform Commission, Uniform Evidence Law (ALRC Report No 102, NSWLRC Report No 112, December 2005).
} 
is the best way to establish the truth or otherwise of an allegation. ${ }^{20}$ An honest witness is 'usually calm and confident in the way ... they give their evidence' distinguishing them from dishonest witnesses; an honest witness will demonstrate 'steadfast resistance to suggestion, coupled with consistent recall of the facts' ${ }^{21}$ Another core assumption is that the parties are legally represented and the parties' legal representatives will conduct cross-examination, and object to any crossexamination that may be inappropriate or offensive.

Although cross-examination is regarded by many as fundamental to a fair adversarial trial process, nonetheless the law has imposed limits on its conduct. ${ }^{22}$ In most Australian jurisdictions the law imposes a duty on the court to disallow questions that are: 'misleading or confusing'; 'unduly annoying, harassing, intimidating, offensive, oppressive, humiliating or repetitive'; 'put to the witness in a manner or tone that is belittling, insulting or otherwise inappropriate'; or have 'no basis other than a stereotype'. ${ }^{23}$ According to the Law Council of Australia, commenting in the family law context, such limitations are sufficient to enable the court to protect the rights and interests of both victims and perpetrators of violence. ${ }^{24}$ The Victorian Law Reform Commission ('VLRC'), discussing the criminal context, however has suggested that the extent and nature of improper questioning are difficult to evaluate in practice and there is a gap between what victims and the legal profession consider appropriate questioning. ${ }^{25}$ Furthermore, according to the Commission, "judicial intervention into improper questioning remains inconsistent' ${ }^{26}$

20 Emily Henderson, 'Bigger Fish to Fry: Should the Reform of Cross-Examination Be Expanded beyond Vulnerable Witnesses?' (2015) 19(2) International Journal of Evidence and Proof 83, 90.

21 Ibid.

22 Questioning of Complainants (n 18) 27-9 [3.13]-[3.21], 33-4 [3.31].

23 Evidence Act 2011 (ACT) s 41(1); Evidence Act 1995 (NSW) s 41(1); Evidence Act 2001 (Tas) s 41(1); Evidence Act 2008 (Vic) s 41(3). The Victorian Act was amended in 2018 after the Victorian Law Reform Commission recommended that judges should be required to disallow improper questions put to all witnesses, not just vulnerable witnesses: Victorian Law Reform Commission, The Role of Victims of Crime in the Criminal Trial Process (Report No 34, August 2016) 98 [5.63]. The Acts in Western Australia and Queensland do not impose a duty on the court in all cases of improper questioning, but rather give the court a discretion to intervene: Evidence Act 1906 (WA) s 26(1); Evidence Act 1977 (Qld) $\mathrm{s} 21$. The Act in the Northern Territory is discretionary except where the witness is vulnerable: Evidence (National Uniform Legislation) Act 2011 (NT) ss 41(1)-(4). South Australian provisions state that an inappropriate question must be disallowed. A determination as to whether a question is inappropriate involves a consideration of both the question and the witness's characteristics: Evidence Act 1929 (SA) ss 25(1), 25(3), 25(4).

24 Law Council of Australia, Submission to the Attorney-General's Department, Family Law Amendment (Family Violence and Cross-Examination of Parties) Bill 2017: Public Consultation on CrossExamination Amendment (2017) 5.

25 The Role of Victims of Crime in the Criminal Trial Process (n 23) 96 [5.49]-[5.52]. See also Russell Boyd and Anthony Hopkins, 'Cross-Examination of Child Sexual Assault Complainants: Concerns about the Application of s 41 of the Evidence Act' (2010) 34(3) Criminal Law Journal 149, 150. The authors suggest that drawing the line between acceptable and unacceptable cross-examination 'is a question of perspective'.

26 The Role of Victims of Crime in the Criminal Trial Process (n 23) 97 [5.60]. It is important to note, as above, that the Victorian provisions in relation to improper questioning do vary from those in most other States and Territories. 
Trials are dynamic processes, adaptive to changing social needs and conditions. ${ }^{27}$ Substantive laws and procedural rules adapt to and reflect changing community standards and contemporary expectations of fairness. ${ }^{28}$ Courts have a duty to maintain public confidence in the administration of justice and the integrity of their processes. This duty is related to the 'legitimacy' of legal proceedings and under the auspices of procedural justice, the legitimacy of courts is a function of the quality of the procedures that are utilised and the perceptions of those involved in such procedures. ${ }^{29}$ Women's Legal Services Australia in their submission to the recent federal parliamentary inquiry into A Better Family Law System, argued that ' $[\mathrm{p}]$ rocedural fairness in legal proceedings should mean that the courts put in place measures to ensure that witnesses can provide their evidence comfortably, and without fear or intimidation'. ${ }^{30}$

Whilst there is a paucity of good quality, and comparable data available across the jurisdictions to accurately record the number of SRLs, ${ }^{31}$ the data that is available suggests there are large numbers of matters involving domestic and family violence where one or both parties are without legal representation. For example, in the NSW Local Court, $23.63 \%$ of defendants convicted of a domestic and family violence related offence during the period October 2015-September 2016 were self-represented. ${ }^{32}$ The Victorian Magistrates' Court, which has the highest volume of cases in that jurisdiction, has no data on the overall number of cases where parties are self-represented, ${ }^{33}$ however, it has been suggested that numbers were increasing in the Magistrates' Court and that ' $[t]$ here are large numbers of people self-representing in family violence matters in the Magistrates' courts, both as applicants and respondents' ${ }^{34}$ In terms of family law proceedings, the Family Court of Australia reported that in 2017-18 one party was selfrepresented at some stage in the process in $17 \%$ of finalised cases, and in $4 \%$ of finalised cases both parties were unrepresented at some stage. ${ }^{35}$ In terms of selfrepresentation at trial in $24 \%$ of cases one party was unrepresented, and in $8 \%$ of cases both parties were unrepresented at trial in 2017-18. ${ }^{36}$

27 Jonathan Doak, Human Rights, Victims Right and Criminal Justice: Reconceiving the Role of Third Parties (Hart Publishing, 2008) 246. See also Tyrone Kirchengast, The Criminal Trial in Law and Discourse (Palgrave MacMillan, 2010).

28 Chief Justice JJ Spigelman, 'The Truth Can Cost Too Much: The Principle of a Fair Trial' (2004) 78(1) Australian Law Journal 29.

29 Kathy Mack and Sharyn Roach Anleu, 'Performing Impartiality: Judicial Demeanour and Legitimacy' (2010) 35(1) Law and Social Inquiry 137, 139.

30 Women's Legal Services Australia, Submission No 6 to House of Representatives Standing Committee on Social Policy and Legal Affairs, Parliament of Australia, Inquiry into a Better Family Law System to Support and Protect Those Affected by Family Violence (27 April 2017) 29.

31 Liz Richardson, Genevieve Grant and Janina Boughey, The Impacts of Self-Represented Litigants on Civil and Administrative Justice: Environmental Scan of Research, Policy and Practice (Report, October 2018) 29-35.

32 Email from NSW Bureau of Crime Statistics and Research to Tracey Booth, 27 February 2017.

33 Department of Justice and Regulation, Access to Justice Review: Volume 2 Report and Recommendations (August 2016) 472.

34 Ibid.

35 Family Court of Australia, Annual Report 17/18 (5 September 2018) 32.

36 Ibid 33. 
The reasons why a person is without representation are varied: 'SRLs are a diverse group, a substantial proportion of whom are socially and/or economically disadvantaged' ${ }^{37}$ Studies have found that the majority of SRLs are without representation because they did not qualify for legal aid and are otherwise unable to afford a lawyer; a small but not insignificant minority choose to represent themselves because for example, they want to represent themselves, have an aversion to lawyers, or think that they can do a better job..$^{38}$

The problem of direct personal cross-examination only arises where the alleged perpetrator of the violence (and the alleged victim in civil proceedings) is without representation. In such cases, there are doubts as to whether direct crossexamination leads to probative evidence that will assist the court. For example, there are concerns about whether the alleged victim of violence is able to give her 'best evidence' if she is being cross-examined by the alleged perpetrator of that harm. ${ }^{39}$ There are also questions about whether an SRL who is the alleged perpetrator of violence has the necessary skills and knowledge to adequately and appropriately test the allegations that are being made against him and satisfy the legal requirements of the legal domain in which the allegation has been raised.

\section{B Impact of Direct Cross-Examination upon Victims of Domestic and Family Violence}

While this article is concerned with direct personal cross-examination of an alleged victim of domestic and family violence by an alleged perpetrator it is important to note that cross-examination is generally recognised as a traumatic experience for victims even when it is conducted by a lawyer. ${ }^{40}$ This traumatic experience is exacerbated, and takes on additional dimensions, when the crossexamination is conducted by the alleged perpetrator of that violence. ${ }^{41}$ For example, in relation to sexual assault proceedings where protections were first introduced to limit direct cross-examination, it was noted that cross-examination by the alleged perpetrator may 'aggravate the humiliation and distress already suffered by the complainant'. ${ }^{42}$ In 2015, Women's Legal Services Australia conducted a survey about women's experiences of being directly cross-examined

37 Richardson, Grant and Boughey (n 31) ii.

38 Ibid 19-22.

39 Questioning of Complainants (n 18) 3 [1.7], 43 [3.59]-[3.60].

40 See, eg, Judith Lewis Herman, 'The Mental Health of Crime Victims: Impact of Legal Intervention' (2003) 16(2) Journal of Traumatic Stress 159; Angela Lynch, Janet Loughman and 'Eleanor', 'Intimate Partner Sexual Violence and Family Law' in Louise McOrmond-Plummer, Jennifer Y Levy-Peck and Patricia Easteal (eds), Perpetrators of Intimate Partner Sexual Violence: A Multidisciplinary Approach to Prevention, Recognition and Intervention (Routledge, 2017) 153, 161; Louise Ellison and Vanessa E Munro, 'Taking Trauma Seriously: Critical Reflections on the Criminal Justice Process' (2017) 21(3) The International Journal of Evidence and Proof 183.

41 See House of Representatives Standing Committee on Social Policy and Legal Affairs, Parliament of Australia, A Better Family Law System to Support and Protect Those Affected by Family Violence (Report, December 2017) 133-4 [4.172]-[4.174] ('A Better Family Law System'); Liz Trinder et al, Litigants in Person in Private Family Law Cases (Report, November 2014) 76. 
in family law proceedings..$^{43}$ Of the 338 women that responded, 147 said that they had experienced direct cross-examination. ${ }^{44}$ Many of the respondents described feeling unsafe, re-traumatised and intimidated, and suffered physical symptoms of stress leading up to and following the court event 'including panic attacks, weight and hair loss, "being physically sick", sleeplessness and post-traumatic stress disorder' ${ }^{45}$ Some comments included:

I felt he had the privilege to continue his intimidation and threats, yet in a confined legal space. It defeats the purpose of having a safety room at court - my support person and I sit there to avoid seeing him, yet we are 'thrown to the wolves' when we enter the courtroom. It made me feel all the feelings all over again. It made me sick to the core.

Couldn't speak very well, frozen.

Terrifying. I could not look at him. The judge later said in his submission that I hated the man cause I couldn't look at him. The man terrorised me for years and to this day is still making me paranoid that he will carry out his death threat. ${ }^{46}$

The potential for poor outcomes when a victim fears personal crossexamination - because the victim decides not to pursue a legal response, or settles for an outcome that is unsafe and/or less than what they would achieve if the matter was litigated - is evident across legal domains. In 2003, the NSWLRC investigating whether personal cross-examination should be limited in sexual offence proceedings, noted that when the then Premier announced that he was going to prohibit direct cross-examination in sexual offence trials, he recognised that the prospect of direct cross-examination may act as a 'disincentive' for some women to 'come forward' and report a sexual offence. ${ }^{47}$ Wood CJ at CL explained in $R v M S K^{48}$ that such consequences could detract from the integrity of the legal proceedings:

The use by [the self-represented accused] of the opportunity to confront and to challenge his alleged victim personally and directly risks diverting the integrity of the judicial process, insofar as it is likely to intimidate the complainant to the point where [they are] unable to give a coherent and rational account of what truthfully occurred. The threat of its occurrence may also discourage a victim of sexual assault from giving evidence or even from making an initial complaint. ${ }^{49}$

The 2015 survey conducted by Women's Legal Services Australia referred to above, found that $39 \%$ of 'matters settled before judgment and $45 \%$ of those respondents said the fear of personal cross-examination by their abuser had been a significant factor in their decision to settle'. ${ }^{50}$ Victoria Legal Aid ('VLA') also

43 Loughman (n 8) 26.

44 Women's Legal Services Australia, Submission to Attorney-General's Department, Family Law Amendment (Family Violence and Cross-Examination of Parties) Bill 2017 (2017).

45 Ibid.

46 Loughman (n 8) 26.

47 Bob Carr (Premier of NSW) quoted in Questioning of Complainants (n 18) 3 [1.5]. Carolyn Hoyle found that in many cases domestic violence victims determined that the emotional cost involved in providing evidence together with other reasons, outweighed the probability of a beneficial outcome from the criminal justice process: Carolyn Hoyle, Negotiating Domestic Violence: Police, Criminal Justice and Victims (Oxford University Press, 1998) 183-93, 214-15.

48 (2004) 61 NSWLR 204.

49 Ibid 218-19 [69].

$50 \quad$ Loughman (n 8) 26. 
noted in a submission to the Better Family Law System inquiry that 'the mere possibility that direct cross-examination could occur can ... cause victims of violence to agree to unsafe consent orders or to abandon [proceedings]'.$^{51}$

Direct or personal cross-examination of a perpetrator of domestic and family violence by the unrepresented victim of that violence is also problematic. As one woman submitted to the 2006 VLRC inquiry into family violence laws:

I have experienced this [personal cross-examination by the respondent] firsthand, and can say that to be cross-examined by the respondent and to have to crossexamine the respondent myself, is not a position I would wish on anyone. I was unprepared, overwhelmed and scared of the prospect of having to look at this man, little less have to talk to him and ask/answer questions. ${ }^{52}$

The 2015 Victorian Royal Commission into Family Violence ('RCFV') presented a case study which documents a similar experience. In a witness statement to the RCFV, 'Rebecca' detailed her private application for a civil protection order and the final hearing for that order. Rebecca represented herself while her former partner, the defendant in the proceedings, had legal representation. Because she had not realised that the matter was listed for hearing she was unprepared to present her case:

In the break I called everyone I knew, but no one could get out of work to come down to help me. After lunch, the hearing was called back on and Dad still wasn't there. I had to stand up and represent myself. I didn't have any support people present. I wasn't prepared at all. Stupidly, I had deleted the text message which contained the threat to kill, just three days earlier. I didn't have any witnesses present. I then had to cross-examine my ex-partner. I don't even know what came out of my mouth. I was like jelly the whole time. It was horrible. At the end, the Magistrate was not convinced that I had enough proof and said it was a case of ' $\mathrm{He}$ said, she said'. The final intervention order was not granted..$^{53}$

Not only can the impact of direct cross-examination upon a victim of domestic and family violence be traumatic, but the same incidents of violence and the same parties may be the focus of multiple proceedings. Victims of family violence might seek a legal response for the same harm from a multiplicity of legal domains. ${ }^{54}$ Lynch and colleagues recount the story of 'Eleanor' who was a victim of sexual and other family violence; she had been granted a protection order in a Victorian Magistrates' Court and a week later, she was in the Federal Magistrates Court (now the Federal Circuit Court of Australia) for a parenting hearing:

I was sick to my stomach to discover on day one of the hearing that he had become a self litigant and was going to be directly cross-examining me ... That day I stood on the stand and the federal court allowed him to directly cross-examine me was a massive slap in the face. How could they give my rapist his power back over me? He asked questions I was forced to answer; he was only meters from me ... How

$51 \quad$ A Better Family Law System (n 41) 134 [4.175].

52 Victorian Law Reform Commission, Review of Family Violence Laws (Report No 185, 1 March 2006) 397 [11.27].

53 Witness statement of 'Rebecca Smith' quoted in Royal Commission into Family Violence: Report and Recommendations (Final Report, March 2016) vol 1, 256 [19].

54 Family Violence: A National Legal Response (n 9) 139 [3.2]. See also discussion in Stubbs and Wangmann (n 9). 
could this happen when another magistrate had said that this circumstance was not appropriate or safe for me? ?5 $^{55}$

Eleanor's experience demonstrates that protections from direct crossexamination can be available in some legal domains, but not others, even where the parties and subject harm is the same. The statutory protections available in those different sites appear to reflect the multiple and competing conceptions of victims of domestic and family violence that emerge in different domains of legal practice. ${ }^{56}$ The same harms and the same parties are subject to different questions, different legal requirements, positioning and constructions. In Part III, we examine the various statutory protections available in criminal proceedings and civil protection order proceedings across Australia.

\section{THE LEGISLATIVE PROTECTIONS}

Australian state and territory governments have responded to concerns about direct cross-examination by introducing differing degrees of protection. In this Part, we examine the statutory frameworks in each jurisdiction as they relate to protections from personal cross-examination across different legal proceedings. ${ }^{57}$ This task has been harder than anticipated - as the Northern Territory ('NT') Review of Vulnerable Witness Legislation Report stated in 2011:

It is difficult to compare the vulnerable witness legislation in each state and territory as, like the NT, most jurisdictions do not have one piece of legislation which contains vulnerable witness protections. Rather, the protections are found throughout legislation relating to evidence and court procedure. Further, each jurisdiction has a different definition of vulnerable witness and, often, various categories of vulnerable witness. ${ }^{58}$

This article examines the provisions as written and refers to the very small number of cases that have made any commentary on the operation of these provisions; we are unable to assess the implementation of this legislation because, with the exception of some anecdotal evidence that emerges in submissions to various inquiries, there is a dearth of research about how these provisions operate in practice.

\section{A Protections in Criminal Proceedings}

All Australian state and territory jurisdictions ${ }^{59}$ have legislated to protect adult complainants in sexual offence proceedings from direct cross-examination by an unrepresented defendant. ${ }^{60}$ Many jurisdictions also extend this type of protection

55 Lynch et al (n 40) 157-8.

56 Stubbs and Wangmann (n 9) 113-25.

57 This article does not examine other protections or limitations on cross-examination for vulnerable witnesses such as the use of audio-video link or screens.

58 Department of Justice (NT), Review of Vulnerable Witness Legislation (Report, June 2011) 6.

59 At the Commonwealth level protection is provided to adult complainants in slavery and slavery-like offences, and in trafficking in persons offences: Crimes Act 1914 (Cth) ss 15Y(2), 15YG.

60 Evidence (Miscellaneous Provisions) Act 1991 (ACT) s 48; Criminal Procedure Act 1986 (NSW) s 294A; Sexual Offences (Evidence and Procedure) Act 1983 (NT) s 5; Evidence Act 1977 (Qld) s 21N; 
to adult victims in other criminal proceedings involving domestic and family violence, offences involving violence, or criminal offences more generally. ${ }^{61}$ The statutory frameworks share two common features; (1) each jurisdiction employs an intermediary model whereby a person asks the questions on behalf of the accused in cross-examination; and (2) generally requires the court to explain to the accused the consequences of failing to cross-examine the victim, in particular, that they will not be able to lead evidence that contradicts the victim's testimony. In addition, if the accused is unrepresented in a jury trial, the judge will explain the limitations imposed on the accused's entitlement to cross-examine the victim and warn the jury that it cannot draw adverse inferences as a result. For example, the Criminal Procedure Act 1986 (NSW) section 294A(7) provides that the judge must:

(a) inform the jury that it is standard procedure in such cases to appoint the person to put the questions to the complainant, and

(b) warn the jury not to draw any inference adverse to the accused person or to give the evidence any greater or lesser weight because of the use of that arrangement.

Despite these commonalities, the statutory frameworks vary in terms of: the type of proceedings in which the protection can be invoked; whether the protection is mandatory or discretionary; the identity or qualifications of the intermediary who asks the questions; and whether the protection extends to witnesses other than the victim of the crime.

\section{Sexual Offence Proceedings}

All Australian jurisdictions prohibit direct cross-examination of an adult victim in sexual offence proceedings by an unrepresented accused. NSW first introduced the protections in 2003 with Tasmania being the last jurisdiction to do so in 2013. Protections were enacted in NSW and Victoria following law reform inquiries that recommended the introduction of prohibitions on personal crossexamination of adult complainants in sexual offence proceedings. ${ }^{62}$ While both the NSWLRC and the VLRC noted that direct cross-examination was rare in these proceedings, ${ }^{63}$ they recommended the prohibitions be introduced nonetheless due to the public interest in protecting complainants from distress and to prevent defendants refusing legal assistance in order to try to gain advantage from direct personal confrontation. More recently, the ALRC and NSWLRC recommended that such protections should also extend to cover other vulnerable witnesses in sexual offence proceedings. ${ }^{64}$

\footnotetext{
Evidence Act 1929 (SA) s 13B; Evidence (Children and Special Witnesses) Act 2001 (Tas) s 8A; Criminal Procedure Act 2009 (Vic) ss 353(1)(a), 356; Evidence Act 1906 (WA) s 106G.

61 Evidence (Miscellaneous Provisions) Act 1991 (ACT) s 48; Evidence Act 1977 (Qld) s 21N; Evidence Act 1929 (SA) s 13B; Evidence (Children and Special Witnesses) Act 2001 (Tas) s 8A; Criminal Procedure Act 2009 (Vic) ss 353(1)(b), 356; Evidence Act 1906 (WA) s 25A.

62 Questioning of Complainants (n 18) 45-7 [3.65]-[3.72]. In Victoria this was part of a wider reference: Victorian Law Reform Commission, Sexual Offences (Report No 78, July 2004) 244-5.

63 Questioning of Complainants (n 18) 4-5; Sexual Offences (n 62) 233.

64 Family Violence: A National Legal Response (n 9) 1343 (Recommendation 28-5).
} 
The validity of the NSW provision was challenged in $R v M S K .{ }^{65}$ In this case the defendants had been charged with numerous sexual offences and were unrepresented at trial. ${ }^{66}$ When the time came for cross-examination of the complainant the defendants refused both the offer of counsel and a person appointed by the court to conduct the cross-examination of the complainant on their behalf pursuant to section 294A of the Criminal Procedure Act 1986 (NSW). As a result, no cross-examination took place. On appeal from their conviction, the defendants argued that the section was invalid for various reasons and that its application led to unfairness and a fundamentally flawed trial' ${ }^{67}$ The NSWCCA dismissed the appeal with Wood CJ at CL reflecting on the trauma experienced by complainants in sexual offence proceedings and how this would be exacerbated if a defendant was able to conduct direct cross-examination. ${ }^{68}$ His Honour also noted that given the defendants refused legal representation for the purposes of conducting cross-examination as provided under this provision, then 'it is difficult to see why they have any basis whatsoever for claiming that they were denied a fair trial'. ${ }^{69}$

Table 1 presents a summary of the relevant provisions across all Australian jurisdictions and the marked lack of uniformity in the approaches adopted is clear. There is no common definition of 'sexual offence' for this purpose and the protections apply to a range of sexual offences. Protections are mandatory in all jurisdictions though in this regard Queensland distinguishes between 'prescribed special offences' and 'prescribed offences'.$^{70}$ In relation to the latter, the protection only applies where the court is satisfied that the victim is 'likely to be disadvantaged as a witness, or to suffer severe emotional trauma unless treated as a protected witness'. ${ }^{71}$ In a recent Queensland case the unrepresented accused sought to argue on appeal that he was denied a fair trial as a result of this mandatory provision, and that the appointment of counsel to conduct the cross-examination put this important component of the trial in 'the hands of someone who was not really the defendant's lawyer'. ${ }^{72}$ The Court of Appeal rejected this argument in very clear terms noting that counsel appointed is subject to 'all of the duties to the client, subject to the ethical constraints to which any advocate representing and accused person is subject'. ${ }^{73}$

While the protection is also mandatory in Western Australia ('WA'), the victim can waive that protection and consent to direct cross-examination. ${ }^{74}$ Another key difference between the jurisdictions is the qualifications of the intermediary who asks the questions on behalf of the accused. In Tasmania,

66 Five men had been charged in relation to these sexual assaults. The trials were split on the application of the three defendants who were represented: $R v M A K$ [2003] NSWSC 849.

$67 \quad R v \operatorname{MSK}$ (2004) 61 NSWLR 204, 211 [26] (Mason P).

68 Ibid 218-19[65]-[71].

69 Ibid $219[78]$.

70 Evidence Act 1977 (Qld) s 21M.

71 Ibid s $21 \mathrm{M}(1)(\mathrm{d})$.

$72 R v$ Mentink [2018] QCA 180, [52] (McMurdo P). This case concerned sexual offences against a child.

73 Ibid [53] (McMurdo P).

74 Evidence Act 1906 (WA) s 106G(2). 
Victoria, South Australia ('SA') and Queensland the intermediary must be a lawyer. There is no similar requirement in the other jurisdictions where the intermediary is simply a person appointed by the court ${ }^{75}$ and in WA, the intermediary can be the judicial officer. ${ }^{76}$

75 See, eg, in NSW in Clark v The Queen (2008) 185 A Crim R 1 (which concerned child sex offences) the person appointed to conduct the cross-examination on behalf of the unrepresented accused was a registrar. On appeal the accused sought to argue that the person appointed to conduct the crossexamination should have legal qualifications, the court rejected this argument noting that the legislation imposes no such restriction and that the registrar was an appropriate person: at 17-18 [40]-[43] (Barr J). A deputy registrar was appointed to conduct the cross-examination in MSv The Queen [2017] NSWCCA 252 .

76 Evidence Act 1906 (WA) s 106G(1)(b). In the case of VJS v Western Australia [2017] WASCA 172 (concerning child sex offences) an associate to a District Court judge was appointed to conduct the crossexamination on behalf of the unrepresented accused. 


\begin{tabular}{|c|c|c|c|c|c|}
\hline 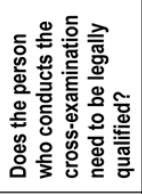 & 2 & 2 & \& & $\underset{\mathscr{J}}{\rightleftharpoons}$ & 岁 \\
\hline 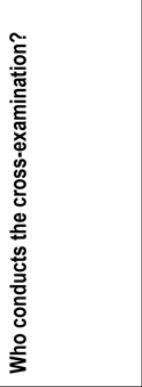 & 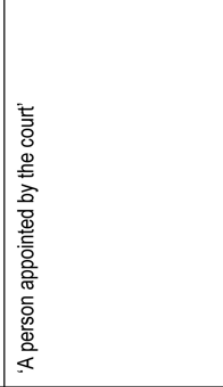 & 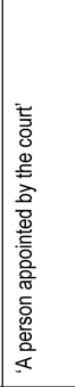 & 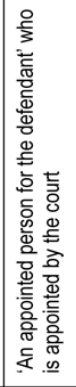 & 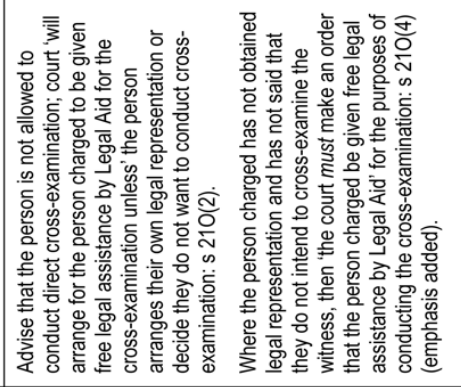 & 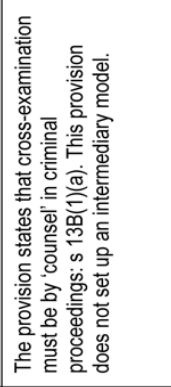 \\
\hline 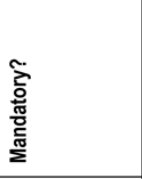 & $\underset{\mathscr{D}}{\rightleftharpoons}$ & 米 & $\stackrel{\mathscr{8}}{=}$ & 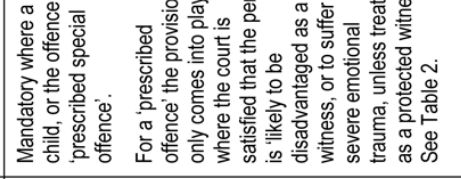 & 造 \\
\hline 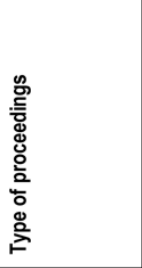 & 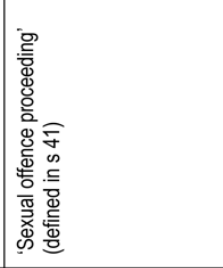 & 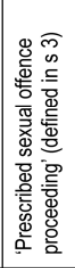 & 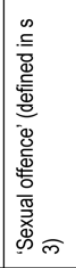 & 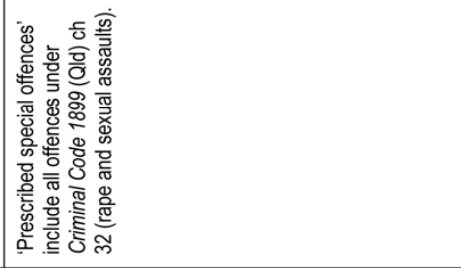 & 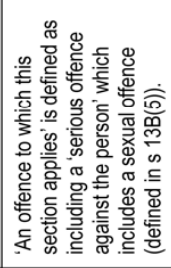 \\
\hline 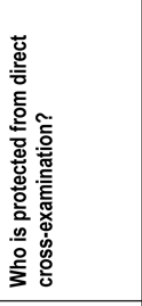 & 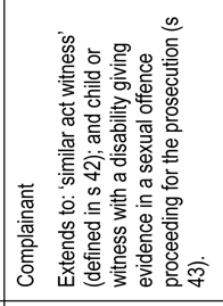 & 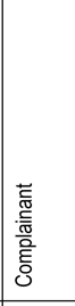 & 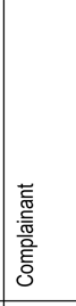 & 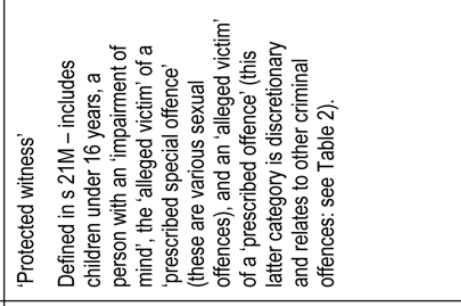 & 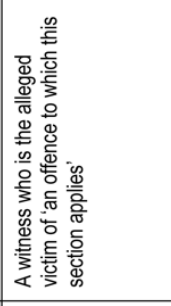 \\
\hline 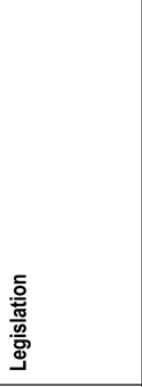 & 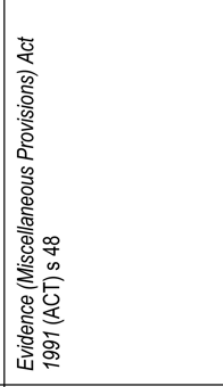 & 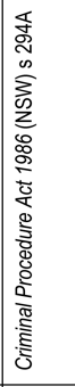 & 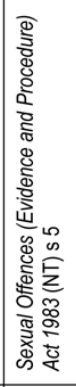 & 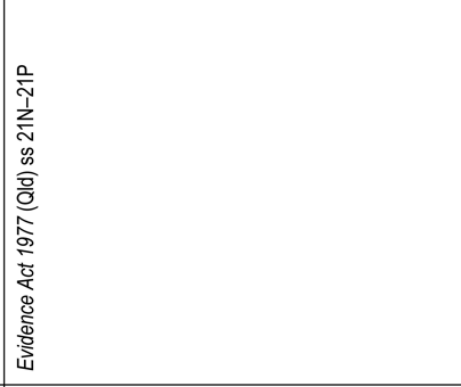 & 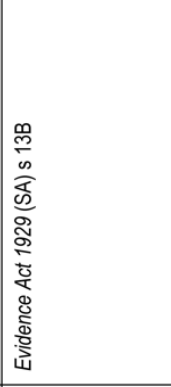 \\
\hline & 点 & 章 & $\mathbf{z}$ & च & 䏍 \\
\hline
\end{tabular}




\begin{tabular}{|c|c|c|c|}
\hline 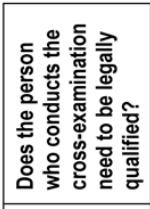 & $\stackrel{\mathscr{S}}{\rightleftharpoons}$ & $\stackrel{\mathscr{L}}{\rightleftharpoons}$ & z \\
\hline 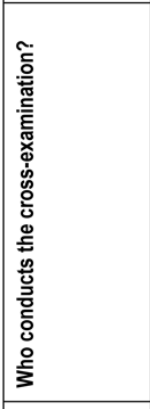 & 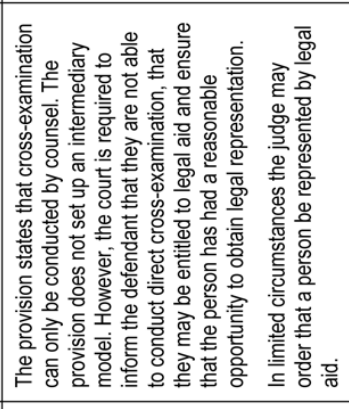 & 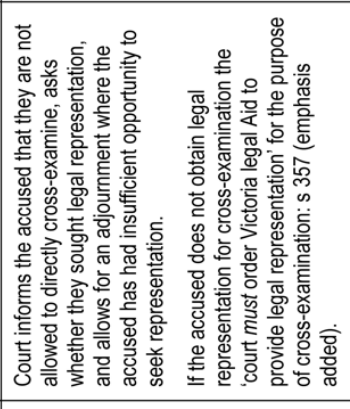 & 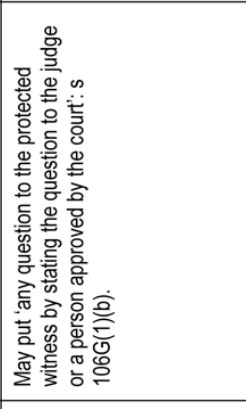 \\
\hline 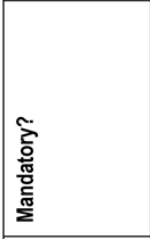 & $\mathscr{\mathscr { D }}$ & $\mathscr{\mathscr { L }}$ & 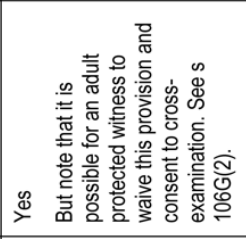 \\
\hline 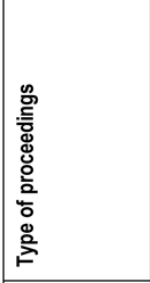 & 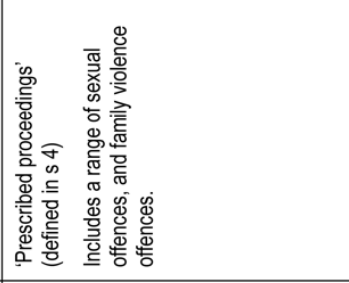 & 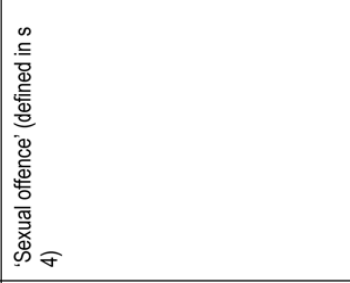 & 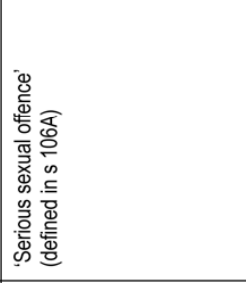 \\
\hline 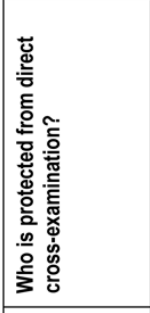 & 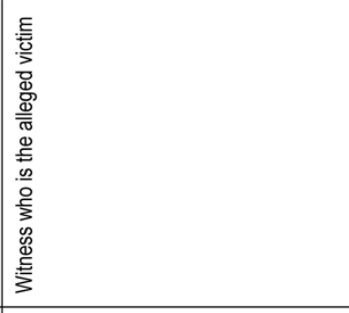 & 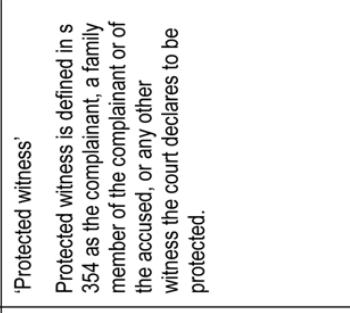 & 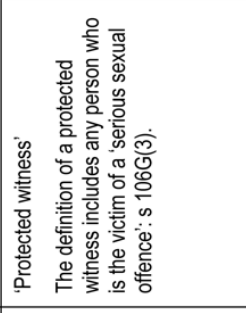 \\
\hline 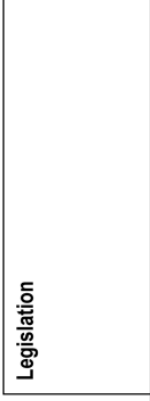 & 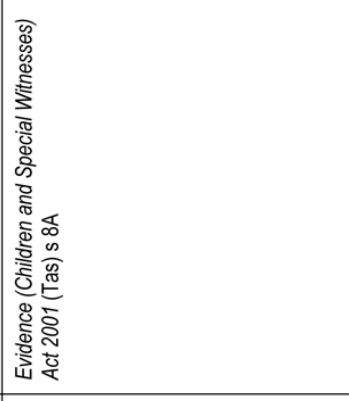 & 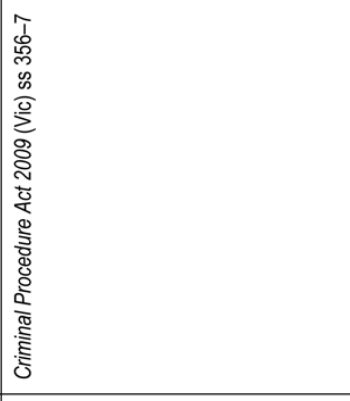 & 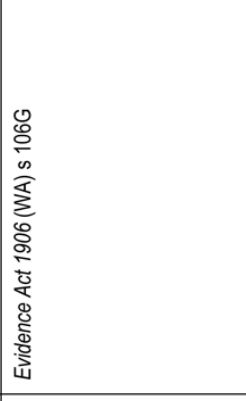 \\
\hline & 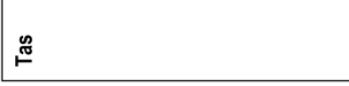 & $>$ & 3 \\
\hline
\end{tabular}




\section{Other Criminal Proceedings}

The extent to which direct cross-examination is limited in other criminal proceedings related to domestic and family violence varies. In those jurisdictions where limits have been imposed the protection may be related to the offence charged, in others it is based on the relationship between the victim and defendant, whilst others look more generally at the vulnerability of the alleged victim. Only NSW and NT do not provide protection from personal cross-examination in other relevant criminal proceedings for victims of domestic and family violence who do not otherwise fall within any special vulnerability provision.

South Australia, Tasmania and Victoria provide protection in relation to certain types of specified offences. ${ }^{77}$ The Australian Capital Territory ('ACT'), however, looks to both the offence type and the witness's characteristics:78 in this jurisdiction protection is provided to the alleged victim in 'serious violent offences', 'family violence offences' and also in relation to 'less serious violent offences' if the court considers that the witness has a vulnerability that affects the witness's ability to give evidence or is likely to suffer severe emotional trauma, be intimidated or distressed by giving evidence..$^{79}$ In Queensland, no direct crossexamination can take place where the witness is considered to be a 'protected witness' ${ }^{80}$ This is automatic for victims of a 'prescribed special offence' whilst for less serious (or prescribed offences) the victim is a protected witness only if the court considers that they 'would be likely to be disadvantaged as a witness, or to suffer severe emotional trauma, unless treated as a protected witness' ${ }^{81}$ In WA, in criminal proceedings not involving a serious sexual offence the protection is discretionary and the court may make an order forbidding direct crossexamination. ${ }^{82}$ Unlike most other jurisdictions however, no particular offences are listed, and when deciding whether to make such an order the court is to have regard, among other matters, to the nature of the charge, the wishes of the witness and the availability of any facilities that might assist the witness to give evidence. ${ }^{83}$

As noted, NSW and the NT are the only jurisdictions that do not extend protection from direct cross-examination to adults without cognitive impairment who are alleged victims of domestic and family violence in criminal proceedings (other than sexual offence proceedings). ${ }^{84}$ In the NT while the definition of

77 Evidence Act 1929 (SA) s 13B; Evidence (Children and Special Witnesses) Act 2001 (Tas) ss 3, 8A; Criminal Procedure Act 2009 (Vic) ss 353, 356.

78 Evidence (Miscellaneous Provisions) Act 1991 (ACT) s 43.

79 Ibid ss 43, 48. 'Family violence offence proceeding', 'less serious violent offence proceeding' and 'serious violent offence proceeding' are defined in ss $38-40$. Vulnerable adult is defined in s 42 .

80 Evidence Act 1977 (Qld) s 21N.

81 Ibid ss $21 \mathrm{M}(1)(\mathrm{c})-(\mathrm{d})$. 'Prescribed special offence' includes very serious offences against the person such as: sexual offences, attempt to murder, acts intended to cause grievous bodily harm (' $\mathrm{GBH}$ '), causing GBH and/or actual bodily harm, and stalking. 'Prescribed offences' include what might be considered less serious offences against the person such as: threatening violence, serious assaults and threats. It is important to note that this provision does not apply to summary offences under the Justices Act 1886 (Qld): ibid s 21L. See also McNicol v Queensland Police Service [2016] QCA 102, [23] (Morrison JA). Evidence Act 1906 (WA) s 25A(1)(c).

83 Ibid s 25A(1).

84 NSW does provide protection to vulnerable witnesses; however, this is very narrowly defined to include a child or cognitively impaired person: Criminal Procedure Act 1986 (NSW) s 306M(1). 
'vulnerable witness' now includes 'a complainant in a domestic violence offence proceeding' and any witness the 'court considers to be vulnerable', ${ }^{85}$ any protections that flow from this in criminal proceedings generally do not include a prohibition from direct cross-examination. This creates the odd position in the NT where a complainant/witness is protected from direct cross-examination in sexual offence proceedings and in civil protection order proceedings (discussed below) but not in criminal proceedings involving offences related to domestic and family violence. In a submission to the NT 2015 Review of the Domestic and Family Violence Act, the President of the Criminal Lawyers Association of the Northern Territory drew attention to the potentially absurd operation of these provisions. ${ }^{86}$ An applicant for a civil protection order will be protected from direct crossexamination in those proceedings, but if the defendant of that order is later charged with breaching it then the alleged victim will not be protected from direct crossexamination in that criminal proceeding. This is despite the fact that a breach might be considered more serious given that it evidences repetitive behaviour in breach of a court order. ${ }^{87}$ In response to the Criminal Lawyers Association's suggestion that the civil protection order legislation be amended to include breach of a civil protection order in the proceedings in which personal cross-examination is not allowed, the Department of the Attorney-General and Justice said:

Victims of an offence are entitled to all the same protections under the Evidence Act and there does not seem to be any reason to provide different protections to a victim when the offence is 'Breach of a DVO' versus an assault occurring in a domestic relationship. A victim of an assault occurring in a domestic relationship would not be automatically classified as a vulnerable witness, yet the victim of a 'breach of DVO' would. This is particularly relevant when the breach may be minor (eg harassing text message, verbal abuse), yet a physical assault charged under the Criminal Code would be far worse. ${ }^{88}$

The Department's response is perplexing, given that almost all other Australian jurisdictions provide protection from direct cross-examination in a wide range of domestic and family violence offences. Rather than considering widening the protection from personal cross-examination to other family violence offences, the response focused on ensuring that the lack of protection is the same across all criminal offences.

Table 2 summarises the relevant provisions limiting direct cross-examination in other criminal proceedings across the jurisdictions. Again, there is variation in terms of whether the protections are mandatory or discretionary. In Victoria, Tasmania and SA the protections are mandatory in the proceedings to which they apply. ${ }^{89} \mathrm{In}$ the ACT, the protection is mandatory if the offence is a 'serious violent offence', except for intellectually impaired witnesses, and in a 'family violence

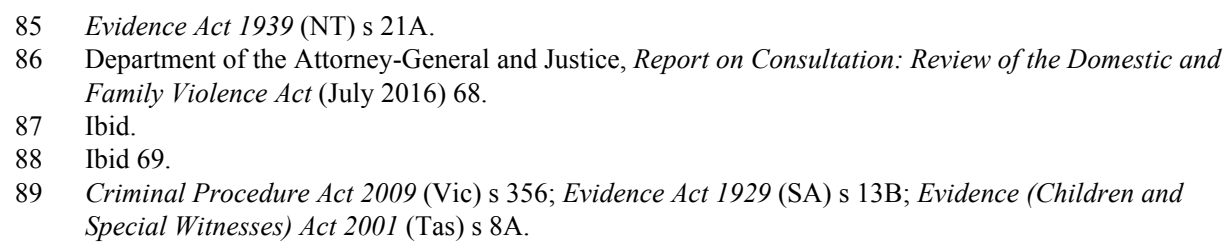


offence' where the violent or other behaviour is in relation to a family member. ${ }^{90}$ Queensland also makes distinctions between different categories of offences; here the protection is mandatory in 'prescribed special offences' but is discretionary in 'prescribed offences' ${ }^{91}$ In relation to 'prescribed offences' the court is to consider whether the alleged victim 'would be likely to be disadvantaged as a witness, or to suffer severe emotional trauma, unless treated as a protected witness'. ${ }^{92}$ In WA the protection is entirely discretionary. In that state, the court in deciding whether the alleged victim should be protected from cross-examination, will have 'regard to the nature of the charge, the wishes of the witness, and the availability of any necessary facilities or equipment ${ }^{\prime}{ }^{93}$ As to who asks the questions on behalf of the unrepresented accused, all jurisdictions other than the ACT and WA require that person to be legally qualified.

Another issue in relation to criminal proceedings (including sexual offence proceedings) is the extent to which the protection extends beyond the direct victim of family violence to other witnesses. Only in Victoria, the ACT and WA does the limitation on direct cross-examination have any wider application. For example, in Victoria the protection applies to a 'protected witness' ${ }^{94}$ who includes the complainant, a family member of the complainant, a family member of the accused or a person declared by the court to be a protected witness. ${ }^{95}$ In the ACT, the protection extends to a 'similar act witness', defined as a person who gives tendency or coincidence evidence in proceedings that 'relates to an act committed on, or in the presence of, the witness by the accused' ${ }^{96}$ In WA protection applies to 'a witness' generally though it is a matter for the court's discretion taking into account the nature of the charge, the wishes of the witness and the availability of alternative arrangement for giving evidence..$^{97}$

90 Evidence (Miscellaneous Provisions) Act 1991 (ACT) ss 42-3, 48. Family violence is defined in Family Violence Act 2016 (ACT) s 8. See Vidovic v Hotchkis [2018] ACTSC 47 in which the accused sought to argue that a previous version of s 48 (s 38D) should not have applied to his case. The Supreme Court rejected any argument that the section constrained the presentation of the accused's case.

91 Evidence Act 1977 (Qld) s 21N, see definition of 'protected witness': at s 21M.

92 Ibid s $21 \mathrm{M}(1)(d)$. See $R v$ Armstrong [2015] QCA 189 in which the accused who had been charged with stalking offences sought to argue that the complainant was not a 'protected witness' and hence he should have been able to directly cross-examine her. This argument was rejected by the Queensland Court of Appeal. The case concerned an older man who was charged with stalking a younger woman at her workplace.

93 Evidence Act 1906 (WA) s 25A(1)(c).

94 Criminal Procedure Act 2009 (Vic) s 356.

95 Ibid s 354.

96 Evidence (Miscellaneous Provisions) Act 1991 (ACT) s 42-3.

97 Evidence Act 1906 (WA) s 25A. It should be noted that witnesses for the prosecution for a criminal organisation offence are expressly protected from personal cross-examination under s 106G. 


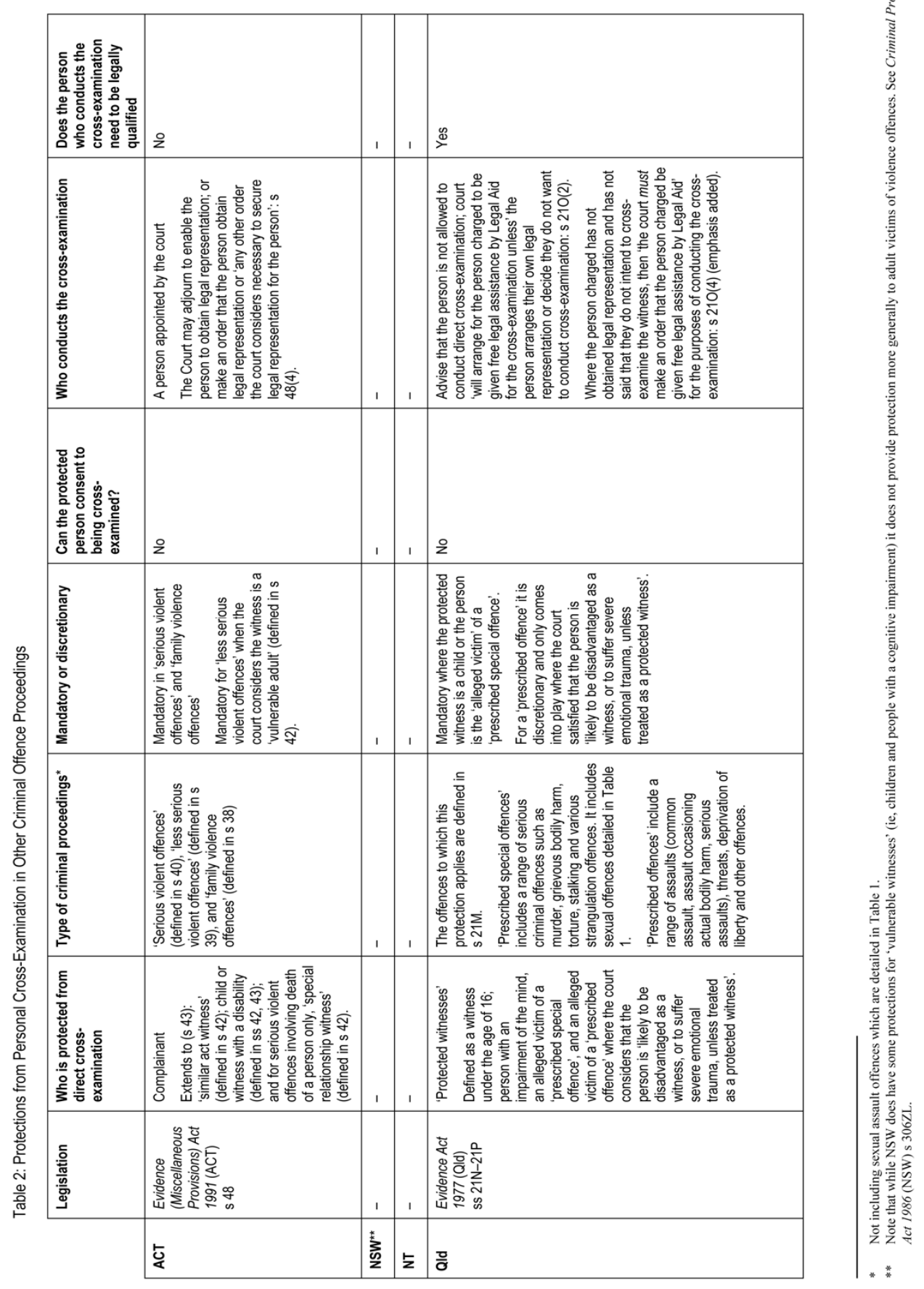




\begin{tabular}{|c|c|c|c|}
\hline 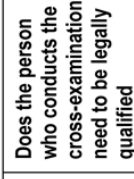 & $\underset{\mathscr{B}}{\rightleftharpoons}$ & $\underset{\mathscr{Z}}{\nearrow}$ & $\stackrel{\mathscr{E}}{\succ}$ \\
\hline 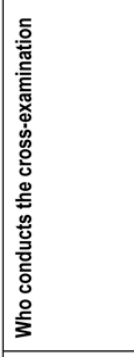 & 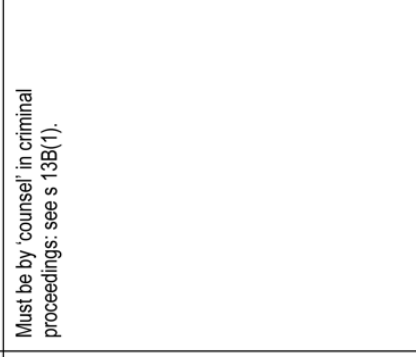 & 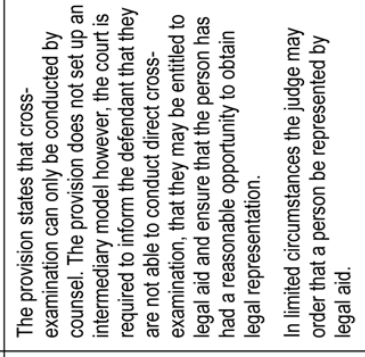 & 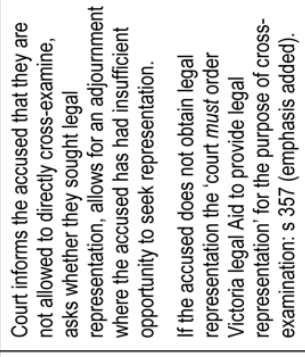 \\
\hline 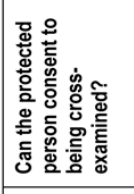 & 2 & z & $\stackrel{2}{2}$ \\
\hline 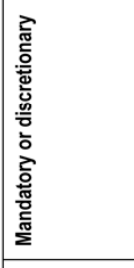 & 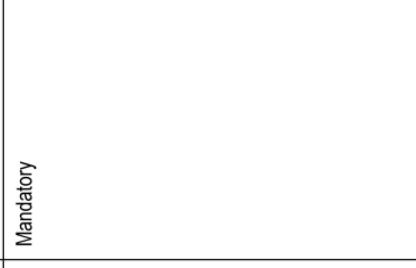 & 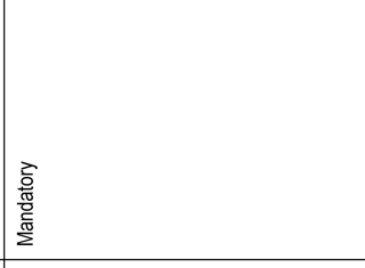 & 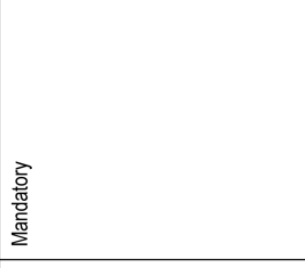 \\
\hline 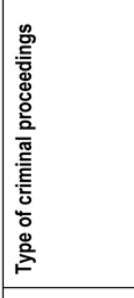 & 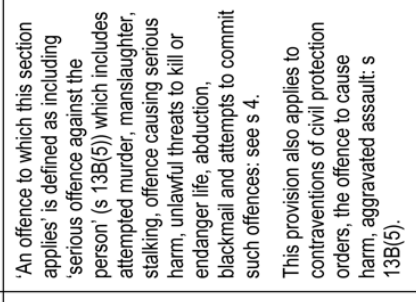 & 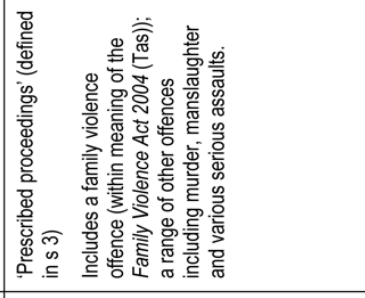 & 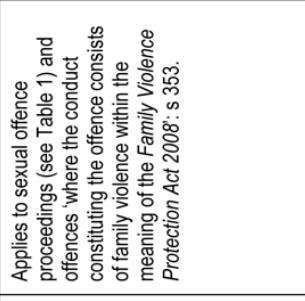 \\
\hline 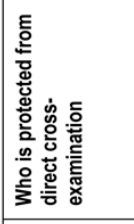 & 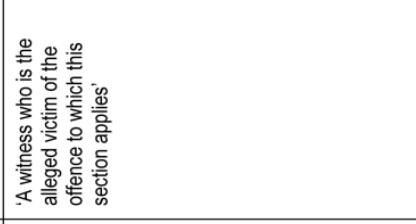 & 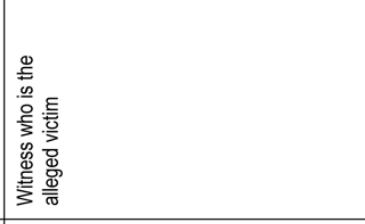 & 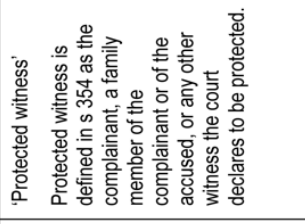 \\
\hline 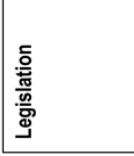 & 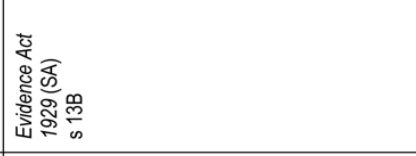 & 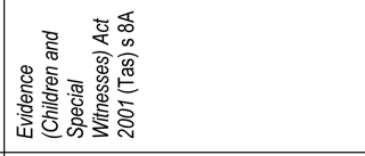 & 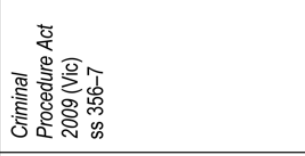 \\
\hline & Ф & $\stackrel{\stackrel{\mathscr{m}}{\circ}}{ }$ & $\stackrel{0}{>}$ \\
\hline
\end{tabular}




\begin{tabular}{|c|c|}
\hline 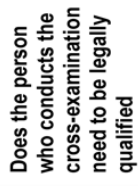 & 2 \\
\hline 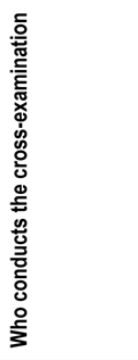 & 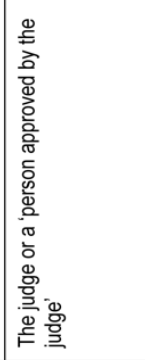 \\
\hline 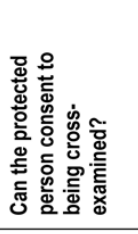 & 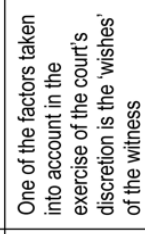 \\
\hline 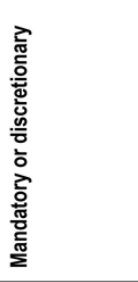 & 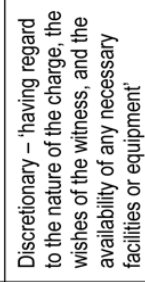 \\
\hline 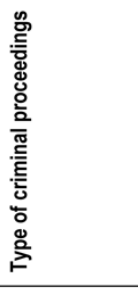 & 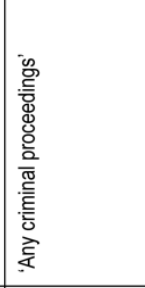 \\
\hline 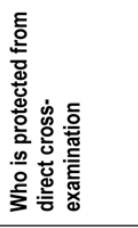 & 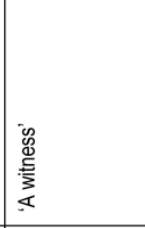 \\
\hline 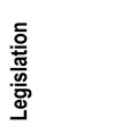 & 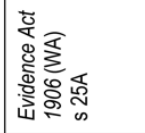 \\
\hline & $\S$ \\
\hline
\end{tabular}




\section{B Civil Protection Order Proceedings}

Civil protection orders are a key feature of Australia's legal response to domestic and family violence. In all Australian states and territories, lower courts can make a civil protection order to restrict a respondent from committing further acts of violence against the applicant. Civil protection orders are the most common legal remedy sought by, or on behalf of, women experiencing domestic and family violence. ${ }^{98}$

With the exception of NSW, every Australian jurisdiction has introduced reforms that prevent self-represented respondents (the alleged perpetrators of the violence) from personally cross-examining adult applicants (the alleged victim of the violence) in civil protection order proceedings. ${ }^{99}$ The ACT is the most recent jurisdiction to do so in response ${ }^{100}$ to the recommendation made by the ALRC and NSWLRC in their 2010 Family Violence report that state and territory protection order legislation should contain such a prohibition. ${ }^{101}$

At the time of writing, NSW remains the only jurisdiction that has not acted on the Commissions' recommendation even though NSW legislation was amended as recently as 2016 to prevent direct cross-examination of a child witness in Apprehended Domestic Violence Order ('ADVO') proceedings. ${ }^{102}$ NSW only protects victims from personal cross-examination in sexual assault trials where personal cross-examination would be much less likely to occur ${ }^{103}$ than would be the case in the context of other criminal matters (particularly those dealt with in the local court) or civil order proceedings.

This gap in NSW leads to domestic violence perpetrators continuing their abuse in the courtroom. In February 2017, The Sydney Morning Herald reported the story of Angela Hadchiti who 'had been beaten so badly by her husband that

98 Heather Douglas and Robin Fitzgerald, 'Legal Processes and Gendered Violence: Cross-Applications for Domestic Violence Protection Orders' (2013) 36(1) University of New South Wales Law Journal 56, 56.

99 Family Violence Act 2016 (ACT) s 63; Domestic and Family Violence 2007 Act (NT) s 114; Domestic and Family Violence Protection Act 2012 (Qld) s 151; Intervention Orders (Prevention of Abuse) Act 2009 (SA) s 29(4); Evidence (Children and Special Witnesses) Act 2001 (Tas) s 8A; Family Violence Protection Act 2008 (Vic) s 70; Restraining Orders Act 1997 (WA) s 44C. In Tasmania, the provisions providing protection against direct cross-examination in civil protection order proceedings are not included in the Act dealing with family violence orders, rather they are contained in Evidence (Children and Special Witnesses) Act 2001 (Tas) s 8A. This provision inserted in 2013 provides that the protection from personal cross-examination applies to anyone giving evidence in respect of a prescribed proceeding for an offence. The language of this provision would appear to exclude applications for a family violence order as this is not an offence, however, 'prescribed proceeding' is defined under s 3 to include an application to a court under part 3 or 4 of the Family Violence Act 2004 (Tas), ie, those parts of the act deal with family violence orders.

100 Explanatory Statement, Family Violence Bill 2016 (ACT) 21.

101 Family Violence: A National Legal Response (n 9) 864 (Recommendation 18-3).

102 Crimes (Domestic and Personal Violence) Amendment (Review) Act 2016 (NSW) sch 1 inserted s 41A in the Crimes (Domestic and Personal Violence) Act 2007 (NSW). In a submission on the 2016 Bill, Women's Legal Service NSW 'strongly urge[d] NSW to take this opportunity to provide vulnerable witness protection from direct cross-examination, beyond the [proposed] protection for a child': Women's Legal Service NSW, 'Letter to the NSW Attorney General in Response to the Crime (Domestic and Personal Violence) Amendment (Review) Bill 2016' (Letter, 10 May 2016) 4 [19].

103 Questioning of Complainants (n 18) 4-5; Victorian Law Reform Commission, Sexual Offences: Law and Procedure (Discussion Paper, September 2001) 129. 
she needed to have a metal plate and screws implanted in her neck. He raped her, he controlled her by installing a tracking device in her car and a listening device on her phone'. ${ }^{104}$ She attended Blacktown Local Court to obtain a final ADVO against her husband and just before her case began she learned that her husband had arrived without a lawyer. He cross-examined both her and her eldest daughter. Although the magistrate allowed Hadchiti and her daughter to face away from her husband during cross-examination, she described it as a 'horrific' experience in which her husband 'was very rude, very controlling. He was swearing, throwing things. He was trying to silence us so we didn't tell our story'. ${ }^{105}$ Her daughter threw up immediately after the cross-examination and was unable to attend school for some days. For Ms Hadchiti, '[t]he experience [of cross-examination] was like reliving a nightmare'. ${ }^{106}$

Table 3 summarises the relevant provisions across the jurisdictions and the disparity in approach documented above for sexual offence and other criminal proceedings is again evident. Protection from direct cross-examination is expressed in clear mandatory terms in the ACT and Tasmania, ${ }^{107}$ while in Victoria and SA, the protection is cast in more equivocal language. Section 70(3) of the Victorian Family Violence Protection Act provides that the respondent 'must not' cross-examine the protected witness unless that witness is an adult who consents to being cross-examined, ${ }^{108}$ and the court decides that such personal crossexamination 'would not have a harmful impact on the protected witness'. In SA, the legislation provides that where the defendant does not have legal representation, the cross-examination is to be undertaken by the Court or the Court's nominee, or 'as otherwise directed by the Court'. ${ }^{109}$ It is unclear whether such directions might include allowing the defendant to conduct the crossexamination if the court considers it appropriate in the circumstances.

Protection from direct cross-examination in the remaining jurisdictions is discretionary. ${ }^{110}$ For example, a Queensland court 'may' make an order prohibiting direct cross-examination of an adult 'protected witness' where the court is satisfied that such cross-examination would cause the 'protected witness' to 'suffer emotional harm or distress' or 'be so intimidated as to be disadvantaged as a

104 Matthew Knott, 'How the Court System Allows Domestic Violence Perpetrators to Continue Abuse', The Sydney Morning Herald (online, 20 February 2017) <https://www.smh.com.au/politics/federal/we-wereterrified-how-the-court-system-allows-domestic-violence-perpetrators-to-continue-their-abuse-20170219gug6hv.html >.

105 Ibid.

106 Matthew Knott, “'A Huge Victory”: Domestic Violence Perpetrators Banned from Cross-Examining Victims' The Sydney Morning Herald (online, 10 May 2017)

$<$ https://www.smh.com.au/politics/federal/a-huge-victory-domestic-violence-perpetrators-banned-fromcrossexamining-victims-20170510-gwlnsi.html $>$.

107 Family Violence Act 2016 (ACT) s 63(2); Evidence (Children and Special Witnesses) Act 2001 (Tas) s $8 \mathrm{~A}(1)$.

108 Consent may be given by a guardian if relevant under the Family Violence Protection Act 2008 (Vic) s $70(3)(b)$.

109 Intervention Orders (Prevention of Abuse) Act 2009 (SA) s 29(4).

110 Domestic and Family Violence Act 2007 (NT) s 114; Domestic and Family Violence Protection Act 2012 (Qld) s 151; Restraining Orders Act 1997 (WA) s 44C. 
witness'. ${ }^{111}$ In WA, the discretionary nature of the provision is on two fronts: the witnesses can themselves request that the protection does not apply, or the court itself can order that it does not apply where it considers that it is "not just or desirable for such an order to be made'. ${ }^{112}$ Despite submissions to the recent review of the Domestic and Family Violence Act 2007 (NT) suggesting that the NT provision be made mandatory, ${ }^{113}$ the legislation was not so amended.

Like the criminal offence protections, the identity and/or relevant qualifications of the person who asks the questions on behalf of the respondent also vary across the jurisdictions. Tasmania, Victoria and Queensland all require that the person who asks the questions on behalf of the respondent is a legal practitioner. For example, in Queensland under section 151(4)(b) of the Domestic and Family Violence Protection Act 2012, if the court has ordered that the respondent cannot directly cross-examine the protected witness, the respondent cannot cross-examine the protected witness unless they have arranged for a lawyer to conduct the cross-examination. ${ }^{114}$ The Victorian and Tasmanian legislation go further. Section 71(1) of the Family Violence Protection Act 2008 (Vic) provides that if the respondent does not have legal representation, the Court must order VLA to 'offer the respondent legal representation for that purpose'. This provision overrides VLA's eligibility requirements though VLA can still require the respondent to contribute to the legal costs. Unlike the Victorian provision, the Tasmanian legislation is not cast in mandatory terms. In Tasmania, 'if it appears to be in the interests of justice that a person should have legal aid ... and that the person has insufficient means to enable [them] to obtain that aid, the judge may make an order' that the person be given assistance under the local legal aid scheme. ${ }^{115}$

In the remaining jurisdictions, the intermediary can be a judicial officer and/or a person nominated or appointed/approved by the court, while the relevant provisions do provide some guidance for non-legal intermediaries, it is sparse and again varies. Section 44C(1)(d) of the Restraining Orders Act 1997 (WA) provides that the respondent 'may put any questions to the person to be examined by stating the question to a judicial officer or a person approved by the court, and that person is to repeat the question accurately to the person to be examined'. ${ }^{116}$ In SA, the defendant is required to submit the questions to be asked in cross-examination to the Court and the Court (or the Court's nominee) will ask the witness 'those of the questions submitted that are determined by the Court to be allowable in crossexamination; or as otherwise directed by the Court'. ${ }^{117}$ Some jurisdictions also specify that (as well as only asking questions put by the defendant) the person

111 Domestic and Family Violence Protection Act 2012 (Qld) s 151(2).

112 Restraining Orders Act 1997 (WA) s 44C(2).

113 Central Australian Women's Legal Service, Submission to Department of the Attorney-General and Justice, Review of the Domestic and Family Violence Act (July 2015) 14-17; Alice Springs Women's Shelter, Submission to Department of the Attorney-General and Justice, Review of the Domestic and Family Violence Act (27 July 2015) 5.

114 See also Evidence (Children and Special Witnesses) Act 2001 (Tas) s 8A.

115 Evidence (Children and Special Witnesses) Act 2001 (Tas) s 8A(3) (emphasis added).

116 Restraining Orders Act 1997 (WA) s 44C(1)(d) (emphasis added).

117 Intervention Orders (Prevention of Abuse) Act 2009 (SA) ss 29(4)(b)(i)-(ii). 
appointed to conduct the cross-examination on behalf of the defendant must not provide the person with legal advice. ${ }^{118}$

As with criminal proceedings above, there is marked variation between the jurisdictions as to the width of the protection. For instance, Tasmania limits the protection to a "witness who is the alleged victim of the offence' 119 while both Victoria and Queensland extend the protection to witnesses beyond the direct victim of family violence. ${ }^{120}$ For example, in Victoria, the protection extends to a 'protected witness' who is defined as: 'the affected family member or the protected person; a child; any family member of a party to the proceedings'; or any person the Court declares to be a protected witness where the Court is satisfied that the witness 'has a cognitive impairment; or 'otherwise needs the protection of the court'. ${ }^{121}$

The protection in the NT extends to a witness in a domestic relationship with the perpetrator of violence as widely defined; ${ }^{122}$ it does not extend to other witnesses appearing in support of a protected person. ${ }^{123}$ Similarly, the protection in the WA legislation extends to the "person with whom the examiner is in a family relationship or an imagined personal relationship'. ${ }^{124}$ The ACT and SA simply extend the protection from direct cross-examination to children who have

118 Family Violence Act 2016 (ACT) s 63(5); Domestic and Family Violence Act 2007 (NT) s 114(3B)(b).

119 Evidence (Children and Special Witnesses) Act 2001 (Tas) s 8A(1).

120 Domestic and Family Violence Protection Act 2012 (Q1d) s 150(1); Family Violence Protection Act 2008 (Vic) ss 70(1)-(2).

121 Family Violence Protection Act 2008 (Vic) ss 70(1)-(2).

122 Domestic and Family Violence Act 2007 (NT) s 9 stipulates:

A person is in a domestic relationship with another person if the person:

(a) is or has been in a family relationship with the other person; or

(b) has or had custody or guardianship of, or right of access to, the other person; or

(c) is or has been subject to the custody or guardianship of the other person or the other person has or has had a right of access to the person; or

(d) ordinarily or regularly lives, or lived, with:

(i) the other person; or

(ii) someone else who is in a family relationship with the other person; or

(e) is or has been in a family relationship with a child of the other person; or

(f) is or has been in an intimate personal relationship with the other person; or

(g) is or has been in a carers relationship with the other person.

123 Ibid s 114.

124 Restraining Orders Act 1997 (WA) s 44C. Section 4 defines a family relationship as a relationship between 2 persons -

(a) who are, or were, married to each other; or

(b) who are, or were, in a de facto relationship with each other; or

(c) who are, or were, related to each other; or

(d) one of whom is a child, that child who-

(i) ordinarily resides, or resided, with the other person; or

(ii) regularly resides or stays, or resided or stayed with the other person; or

(e) one of whom is, or was, a child of whom the other party is a guardian; or

(f) who have, or had, an intimate personal relationship, or other personal relationship with each other. 
witnessed or been exposed to the alleged violence, in addition to the alleged victim seeking protection. ${ }^{125}$

Protection for alleged victims who are self-represented is an issue peculiar to civil protection order proceedings (and family law proceedings). ${ }^{126}$ Unlike criminal proceedings, in civil protection order proceedings the alleged victim who is seeking protection may also be without legal representation and need to crossexamine the alleged perpetrator. In most Australian jurisdictions, protection orders may be sought by the police on behalf of the victim (a police application), or the victim may make their own application (a private application). In police applications the police prosecutor represents the victim in court, however in private applications the victim either instructs a legal representative or represents themselves in court. While the police apply for the vast bulk of civil protection orders, a number of alleged victims may still make their own application for a variety of reasons including not wanting the police to be involved, or the police might have referred the victim back to the court. Those alleged victims who are self-represented may find themselves having to cross-examine the perpetrator at an interim or final hearing. Only Victoria has considered the position of such unrepresented applicants ('protected witnesses') though its recognition of the difficulties faced by applicants in this position is limited. Assistance to unrepresented applicants is not provided for the conduct of their own direct crossexamination of the respondent, but is provided to assist the applicant when the respondent who has been prohibited from conducting direct cross-examination has a legal representative to conduct the cross-examination on his behalf and the applicant does not '[object] to the provision of the legal representation' ${ }^{127}$ This appears to be more of a 'levelling the playing field' provision than a full recognition of the difficulties faced by the applicant where conducting her own cross-examination of the respondent must also be recognised as traumatic.

The nature of this difficulty is highlighted in a WA case of Cramphorn $v$ Bailey. ${ }^{128}$ In this case Cramphorn, a woman, had been convicted of multiple offences against her former de facto. At trial Cramphorn personally crossexamined the complainant (her former partner). On appeal Cramphorn argued that she should not have been allowed to do so (this was one of a number of grounds of appeal). ${ }^{129}$ This argument was unsuccessful on a number of bases (including that the proceeding did not involve a proceeding for a restraining order). Cramphorn's argument was also more complex in that she sought to raise arguments about her own victimisation by the complainant (there was a civil protection order in place that protected her from the complainant at the time of the trial) and she sought to invoke other protections such as having the complainant removed from the

125 Family Violence Act 2016 (ACT) s 63(2); Intervention Orders (Prevention of Abuse) Act 2009 (SA) s 29(4).

126 It is important to note that the recent amendment to the Family Law Act 1975 (Cth) on direct crossexamination does address this issue of unrepresented victims of family violence.

127 Family Violence Protection Act 2008 (Vic) s 72(2).

128 [2014] WASCA 60.

129 Ibid [85] (Mazza JA). 
courtroom ${ }^{130}$ and access to video link or screens. ${ }^{131}$ In an analysis of the provision restricting direct cross-examination, the court concluded that the provision was designed for the protection of the complainant and not the person doing the crossexamination. ${ }^{132}$ This case raises questions about the precarious position of victims of domestic violence who may be subject to cross-applications and hence unable to access the protections that they would be afforded if they were identified as the victim in the proceeding. ${ }^{133} \mathrm{It}$ is also an important question to consider given the increasing concern about women being identified as defendants in domestic violence proceedings where they have used violence in the context of their own victimisation. ${ }^{134}$

130 Ibid [28] (Mazza JA).

131 Ibid [95] (Mazza JA).

132 Ibid [104]-[106] (Mazza JA).

133 For a discussion of cross applications, see Jane Wangmann, 'Gender and Intimate Partner Violence: A Case Study from NSW' (2010) 33(3) University of New South Wales Law Journal 945; Douglas and Fitzgerald (n 98).

134 See NSW Legislative Council Standing Committee on Social Issues, Domestic Violence Trends and Issues in NSW (Report No 46, August 2012) ch 8. 


\begin{tabular}{|c|c|c|c|c|c|c|}
\hline 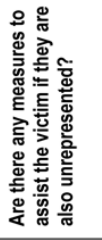 & $\frac{1}{2}$ & 1 & 2 & $\frac{0}{2}$ & $\frac{0}{2}$ & $\frac{0}{2}$ \\
\hline 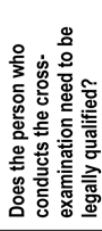 & 2 & 1 & z & 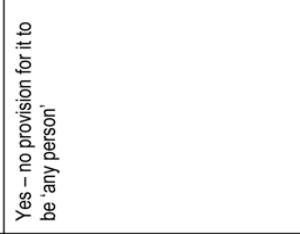 & 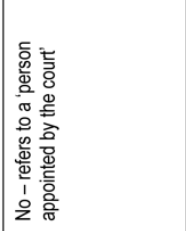 & 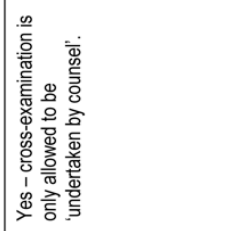 \\
\hline 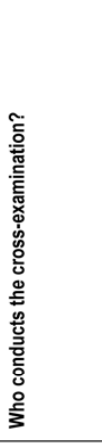 & 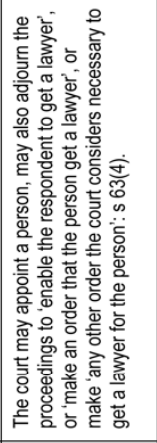 & 1 & 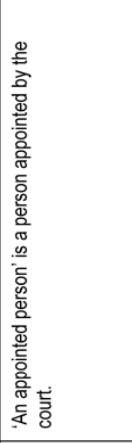 & 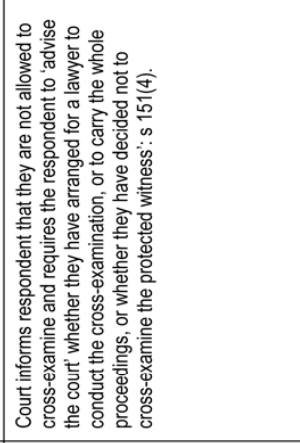 & 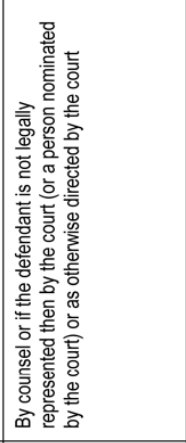 & 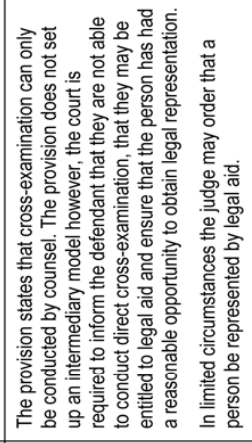 \\
\hline 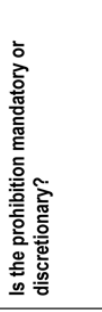 & 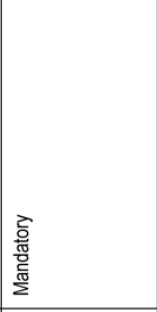 & 1 & 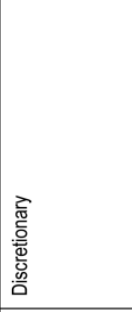 & 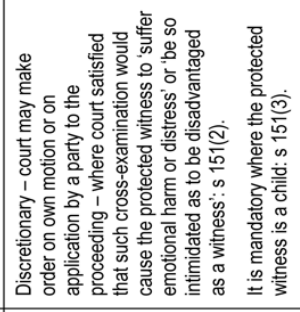 & 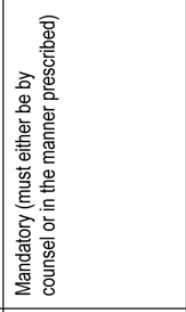 & 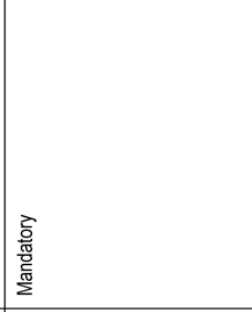 \\
\hline 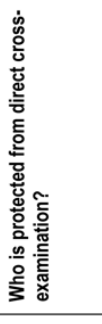 & 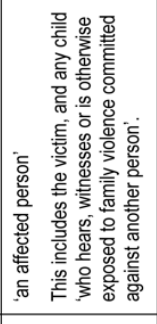 & 1 & 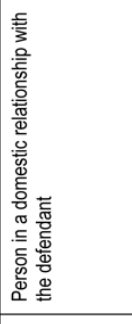 & 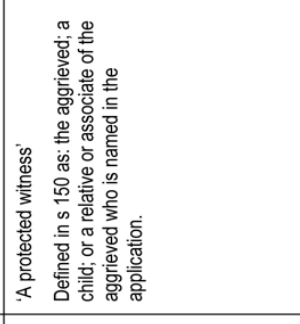 & 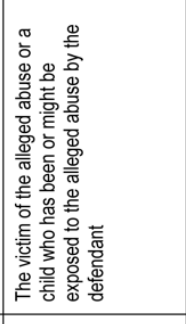 & 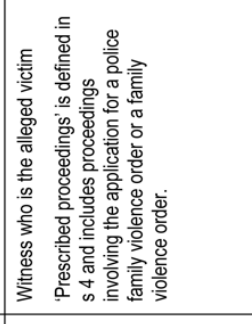 \\
\hline 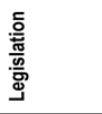 & 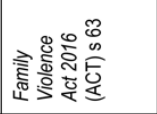 & 1 & 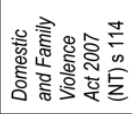 & 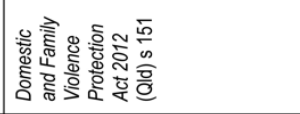 & 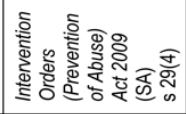 & 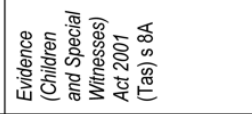 \\
\hline & '气 & $\frac{5}{2}$ & 占 & 응 & ๘ & 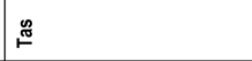 \\
\hline
\end{tabular}




\begin{tabular}{|c|c|c|}
\hline 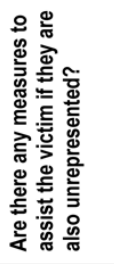 & 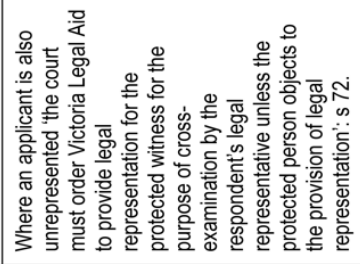 & z \\
\hline 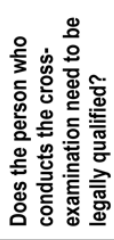 & $\stackrel{\mathscr{B}}{>}$ & 2o \\
\hline 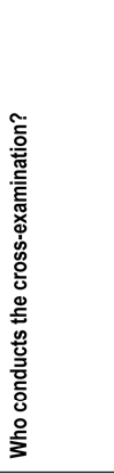 & 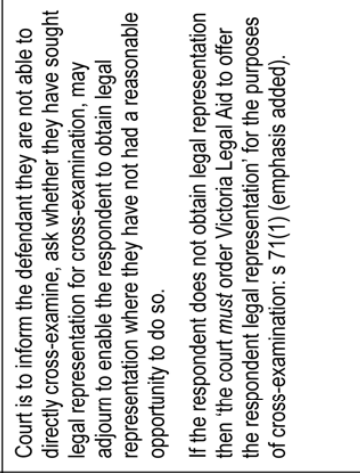 & 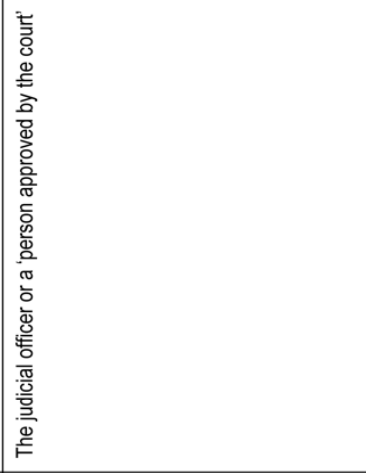 \\
\hline 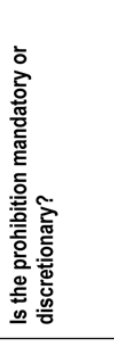 & 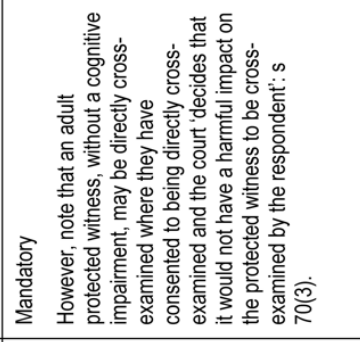 & 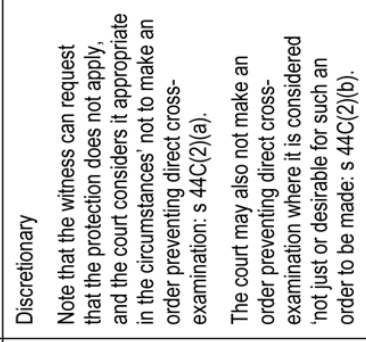 \\
\hline 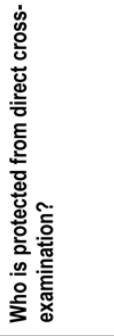 & 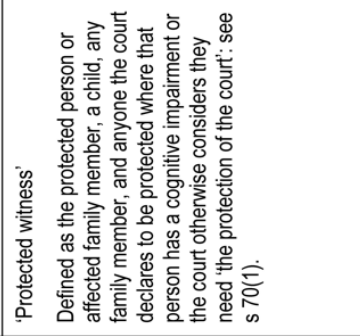 & 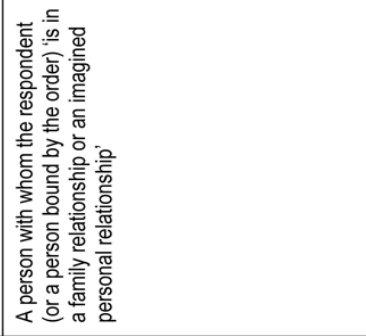 \\
\hline 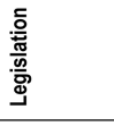 & 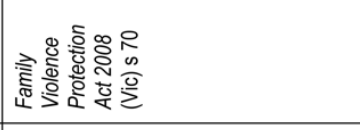 & 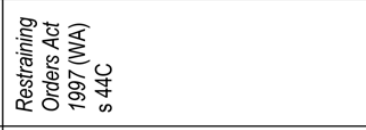 \\
\hline & $\stackrel{0}{>}$ & s \\
\hline
\end{tabular}




\section{GAPS AND DEFICIENCIES}

There is a marked unevenness in the extent to which victims of domestic and family violence are protected from personal cross-examination across Australia. Whether or not a victim is protected in a given matter is essentially a matter of serendipity of the applicable jurisdiction. Whereas alleged victims of sexual violence are protected from personal cross-examination in all Australian jurisdictions, alleged victims of other criminal offences where the subject conduct can be characterised as domestic and family violence are not similarly protected in some jurisdictions. The situation is the same in civil protection order proceedings in which alleged victims of domestic and family violence are not protected against personal cross-examination in NSW and NT though such victims would be protected in other Australian jurisdictions. Moreover, additional issues which arise when the victim of domestic and family violence is without legal representation have only been addressed in Victoria and then only in a limited way. Unevenness in protection for victims of family violence is also apparent within jurisdictions. As noted above, the same incidents of domestic and family violence involving the same parties may be the focus of multiple proceedings. In some jurisdictions such as NSW for instance, it is clear that a victim of domestic and family violence might be protected in one legal domain (criminal proceedings involving sexual assault) but not in other criminal proceedings nor in civil protection order proceedings.

The nature of existing protections also differs and our analysis reveals significant deficiencies in the potential scope of the protection: the mandatory or discretionary nature of the protection, and the intermediary model adopted. These issues are discussed below.

\section{A Mandatory or Discretionary Protection}

A key issue is whether the protection from direct cross-examination is mandatory or discretionary. Our analysis shows that while all jurisdictions have mandatory protection in sexual offence proceedings, the same cannot be said for other criminal and civil protection order matters where in some jurisdictions the protection is expressed in discretionary terms. A discretionary provision requires the court to have regard to particular circumstances before deciding whether it is appropriate to protect the victim from direct cross-examination. At its discretion, a court can decide that it is unnecessary to prohibit personal cross-examination in the circumstances. For example, in Queensland the court has to make a judgment as to whether such cross-examination would cause the victim to suffer emotional harm or distress or to be so intimidated as to disadvantage the victim as a witness. ${ }^{135}$ This provision requires the judge to assess the victim's emotional state and raises the issue of judicial understanding of the dynamics of family violence. There is little in the Act $^{136}$ to assist judicial officers in the exercise of this discretion and in the absence of life experience or comprehensive training, there will be limits on 
the judge's ability to recognise and respond to the difficulties affecting a victim's ability to give evidence. Even an experienced judge with a good understanding of family violence may not be aware that the proposed cross-examination is an extension of the abuse: a seemingly innocuous line of questioning could well have a much more sinister meaning for the victim due to previous abuse patterns. Discretionary judgments might also be underpinned by stereotypical assumptions about victims of domestic and family violence. As a result, where a victim appears to be strong and confident in the courtroom she may be perceived as able to withstand direct cross-examination, yet this still fails to consider whether she is able to give her best evidence in such contexts. Douglas' recent work on coercive control and legal systems abuse is of relevance here. ${ }^{137}$ In her view, legal professionals do not understand that in some cases, the perpetrator uses the legal system to further his control and abuse of the victim. Legal system abuse includes direct cross-examination. ${ }^{138}$ Douglas argues that judicial officers and other legal professionals will make 'more appropriate decisions when they understand [domestic and family violence] ... is manifested in a pattern of coercive control'. ${ }^{139}$ The consistent calls for further education and training evidence continuing issues with the adequacy of legal professionals' (including judicial officers) understanding about the nature of domestic and family violence. ${ }^{140}$

There is a dearth of research in relation to the operation of judicial discretion in such circumstances but VLA in its submission to the recent federal parliamentary inquiry on a Better Family Law System said that is likely to be 'unpredictable, inconsistent and dependent on the discretion of the individual judge'. ${ }^{141}$ Recent research from the UK on direct cross-examination of vulnerable and intimidated witnesses also notes the variability in judicial practice when faced with discretionary provisions. ${ }^{142}$

The increasing reliance on discretionary provisions as we move away from criminal offences and proceedings that are perceived to be more 'serious' towards those protecting victims by civil order is of concern. As the ALRC and NSWLRC noted when it recommended that all jurisdictions should provide protection in these proceedings:

137 Heather Douglas, 'Legal Systems Abuse and Coercive Control' (2017) 18(1) Criminology and Criminal Justice 84.

138 See discussion of the different 'manifestations' of legal systems abuse: ibid 86-96.

139 Ibid 94.

140 See, eg, A Better Family Law System (n 41) xxxvi-xxxvii (Recommendations 27-8); Royal Commission into Family Violence: Summary and Recommendations (Report, March 2016) 27; Special Taskforce on Domestic and Family Violence in Queensland, Not Now, Not Ever: Putting an End to Domestic and Family Violence in Queensland (Report, 28 February 2015) 37-8 (Recommendations 103-5, 107-10); Family Violence: A National Legal Response (n 9) ch 13; Richard Chisholm, Family Courts Violence Review (Report, 27 November 2009) 163-8 [4.4].

141 Victoria Legal Aid, Submission No 60 to House of Representatives Standing Committee on Social Policy and Legal Affairs, Parliament of Australia, Inquiry into a Better Family Law System to Support and Protect those Affected by Family Violence (May 2017) 19.

142 Natalie Elizabeth Corbett and Amy Summerfield, Alleged Perpetrators of Abuse as Litigants in Person in Private Family Law: The Cross-Examination of Vulnerable and Intimidated Witnesses (Report, 2017) $15-28$. 
[W]hile 'the questioning of vulnerable witnesses by unrepresented accused in sexual offence trials is widely recognised as unacceptable', applications for protection orders are 'no different in the relevant dynamics, and, may in fact involve sexual offences, making such court processes a direct comparison'. ${ }^{143}$

Another significant matter of concern is the fact that the mandatory quality of the protection can be abrogated by the victim's consent to cross-examination in some cases. On the one hand, such a provision preserves a victim's autonomy in the process. There may be cases where a victim of family violence feels able to be cross-examined by the perpetrator of that violence. On the other hand, 'consent' in this context is problematic given the constrained and possibly pressured nature of consent in the setting of intimate partner violence. ${ }^{144}$ The coercive and controlling nature of family violence means that there will be cases where the victim is persuaded at best, or bullied at worst, to agree to direct cross-examination by the perpetrator. It is also likely that in many cases, a judge would not anticipate or be aware of any coercion experienced by the victim, particularly those judges who lack an understanding of the nature of family violence and accept the victim's consent to the cross-examination.

\section{B The Intermediary Model}

All statutory frameworks employ an 'intermediary model' in the event that the alleged perpetrator of domestic and family violence is prohibited from direct crossexamination of the alleged victim of that violence. Under this model, an intermediary is substituted for the alleged perpetrator for the purpose of asking questions in cross-examination of the alleged victim. Our analysis reveals that the identity and/or qualifications of the intermediary are key variables that differ across the jurisdictions.

In some cases, the relevant provisions do not require the intermediary to have legal qualifications and/or be a practising lawyer. An obvious problem with an intermediary without legal training is the lack of expertise about legal and procedural requirements relevant to the conduct of a cross-examination. Where the intermediary is a non-lawyer, the provisions generally require the intermediary to ask the questions crafted by the accused ${ }^{145}$ and make it clear the intermediary is not to provide legal advice. ${ }^{146}$ Less common are provisions that allow the intermediary to be the judicial officer or nominee. ${ }^{147}$ Clearly, this model is problematic because of the challenge it poses to the appearance of judicial neutrality.

143 Family Violence: A National Legal Response (n 9) 862 [18.140].

144 Rosemary Hunter, 'Consent in Violent Relationships' in Rosemary Hunter and Sharon Cowan (eds), Choice and Consent: Feminist Engagements with Law and Subjectivity (Routledge-Cavendish, 2007) 158, 165-9.

145 Evidence Act 1906 (WA) s 106G.

146 See, eg, Sexual Offences (Evidence and Procedure) Act 1983 (NT) s 5; Evidence (Miscellaneous Provisions) Act 1991 (ACT) s 48(3). In NSW, a detailed procedure is set out in the Criminal Trial Courts Bench Book published by the Judicial Commission. Furthermore, following Clark v The Queen (2008) 185 A Crim 1, the bench book suggests that intermediaries appointed to conduct the cross-examination on behalf of a self-represented defendant should be present in court to hear the witness give evidence in chief beforehand: Judicial Commission of New South Wales, Criminal Trial Courts Bench Book (2002) 147-52 [1-840]-[1-880] <https://www.judcom.nsw.gov.au/publications/benchbks/criminal/index.html>. 
Many of the legislative provisions analysed require that the intermediary appointed be a lawyer. A common feature across the legislative frameworks is that the lawyer is employed for the purposes of conducting the cross-examination only and not the conduct of the defence strategy more generally, which is usually the role of the alleged perpetrator's lawyer. ${ }^{148}$ As the last jurisdiction to introduce personal cross-examination protections, Tasmania had the benefit of looking at models used by all the other jurisdictions. In the Second Reading Speech on the Tasmanian Bill introducing these provisions, the Minister said:

Unfortunately, there is little consistency in the provisions adopted in other jurisdictions ... Of the alternatives, representation by a lawyer was considered preferable for two reasons. Firstly, a lawyer will be familiar with how to crossexamine a witness, something that should be of benefit to the accused. Secondly, having a member of court staff cross-examine a victim or key witness may diminish the apparent objectivity of the court. ${ }^{149}$

The ALRC and NSWLRC also considered this issue in its extensive work on family violence laws and noted that advantages of a lawyer representing the perpetrator include

benefits associated with the professional duty the lawyer owes to the court and the client; the skills that lawyers bring to this work in terms of understanding the rules of evidence; the public interest in testing the evidence presented by the witness, and in addressing the imbalance between the prosecution and the unrepresented defendant. ${ }^{150}$

While there are clear advantages in appointing a lawyer as the intermediary, this solution is nonetheless problematic for several reasons. Caruso argues that to represent the perpetrator for the purposes of the cross-examination only, raises ethical and professional problems for lawyers. ${ }^{151}$ Lawyers have an ethical and professional duty to 'ensure an appropriate defence is put in a fair manner so as to ensure the court is not misled and appraised of all relevant information'. ${ }^{152}$ In being limited to the conduct of cross-examination, the lawyer is reduced to a 'mouthpiece' and could be required to ask questions that they regard as 'unwise' or 'adopt a case strategy they believe contrary to the interests' of the perpetrator. ${ }^{153}$

The requirement of a legal representative to conduct the cross-examination also raises issues of fairness. If the alleged perpetrator cannot afford and/or locate a legal representative for this purpose, then he might be denied the opportunity to properly present his case. Several commentators regard such a result as significantly detracting from the perpetuator's entitlement to a fair hearing. Many of the models that require a lawyer to conduct the cross-examination circumvent

148 David Caruso and Timothy Cross, 'The Case in Australia for Further Reform to the Cross-Examination and Court Management of Child Witnesses' (2012) 16(4) International Journal of Evidence and Proof 364, 382-9.

149 Tasmania, Parliamentary Debates, House of Assembly, 26 September 2013, 22-83 (Brian Wightman).

150 Family Violence: A National Legal Response (n 9) 1342 [28.130].

151 David Caruso, 'Proposed Reforms for the Cross-Examination of Child Witnesses and the Reception and Treatment of their Evidence' (2012) 21(4) Journal of Judicial Administration 191, 205-6. See also ibid $1342[28.131]$.

152 Caruso (n 151) 206.

153 Ibid 205. 
this outcome to a certain extent by further stipulating that the legal aid organisation in the relevant jurisdiction is to provide the legal representation for that purpose. For instance, under the Victorian legislation the Court must order VLA to represent the perpetrator for the purposes of cross-examination. ${ }^{154} \mathrm{In}$ its submission to the RCFV, VLA noted that in 2013-14 the court had ordered representation for the cross-examination only for 308 applicants and 192 adult respondents in civil order proceedings. ${ }^{155}$ In many instances the VLA provides assistance to the person for the entire proceedings. However, whether legal aid organisations can offer this expanded form of representation is a question of resources and inevitably the response of legal aid organisations will differ across the jurisdictions. ${ }^{156}$

From the victim's perspective however, regardless of who asks the questions, the models do not protect the alleged victim from questions crafted by the perpetrator in the case of non-legal intermediaries nor those shaped by an alleged perpetrator's instructions in the case of a legal intermediary. ${ }^{157}$ Those questions might be designed to continue the abuse of the victim and on the face of it, this might not be apparent to the court or the intermediary whose job it is to pose those questions to the victim.

Ultimately, a dearth of research and inquiry into these issues means that we know very little about the application and operation of these provisions. Management of legal proceedings and the conduct of cross-examination are matters for the court in its administration of justice, and inevitably, courts will differ both across and within jurisdictions in terms of their knowledge and response to particular cases. However, given these legislative provisions can significantly impact on a party's ability to present their case, it is likely that courts will tend towards a narrow interpretation of the relevant provisions. This point is reinforced by the NSW Court of Criminal Appeal's comments in its consideration of the operation of the intermediary model under section 294 of the Criminal Procedure Act 1986 (NSW) in Clarkv The Queen: 158

The purpose of ... [section] 294A is to spare the complainant in the trial of a person accused of a prescribed sexual offence the need to answer questions directly asked of [them] by the person said to have committed the offence. ... since the section takes away or modifies rights which accused persons are ordinarily taken to possess, it should be applied in a manner no broader than is sufficient to achieve its purpose. ${ }^{159}$

154 Family Violence Protection Act 2008 (Vic) s 71(1).

155 Victoria Legal Aid, Submission to Royal Commission into Family Violence (June 2015) 60.

156 In the family law context we note the federal government's recent announcement to provide extra funding to legal aid commissions to enable them to conduct cross-examination in family law proceedings involving family violence where one or both parties are without legal representation: see above $\mathrm{n} 13$. This funding appears to be confined to the conduct of cross-examination only.

157 Caruso and Cross (n 148) 384-7.

158 (2008) 185 A Crim R 1.

159 Ibid 17 [40] (Barr J). This case also serves to highlight the "practical difficulties of implementing the procedure' in a rural area: David Brown et al, Criminal Laws: Materials and Commentary on Criminal Law and Process of New South Wales (Federation Press, $6^{\text {th }}$ ed, 2015) 699-700. 


\section{CONCLUSION}

It is well documented and non-contentious that direct cross-examination of an alleged victim of domestic and family violence, or the prospect of that crossexamination, by an unrepresented alleged perpetrator of that violence is problematic because of the potential negative impact on alleged victims. The direct cross-examination of an alleged perpetrator of family violence by the unrepresented alleged victim of that violence in civil proceedings, though less documented, is just as problematic. For many alleged victims, such direct confrontation with the alleged perpetrator of violence is perceived as a continuation of the violence. The negative impacts on wellbeing include trauma, distress, and unsafe or disadvantageous outcomes.

However, from a traditional legal perspective, cross-examination is fundamental to a fair hearing and a lynchpin of adversarial legal proceedings. Any erosion of parties' entitlement to cross-examine is said to undermine the presumption of innocence in criminal matters and the traditional rules of procedural justice more generally. The entitlement to cross-examine is not unfettered however, and the law does impose limitations on the nature and content of questions that can be asked. The effectiveness of these limitations is dependent upon the responses of the lawyers and judges involved. An important assumption underpinning this legal process is that the parties are legally represented and it is evident that in case of self-represented alleged perpetrators of violence, there is a significant disjuncture between the law and the interests and concerns of victims of family violence.

Nonetheless, a shift in community sensibilities has broadened the conception of 'fairness' in legal proceedings to include the experiences of alleged victims of crime in particular circumstances. Changes to the law have focused on the identification of and introducing protections for vulnerable witnesses and this article has examined the legislative protections introduced in Australian states and territories to protect alleged victims of domestic and family violence from direct cross-examination by the unrepresented alleged perpetrator of that violence.

However, 'there is no single "family violence law" in Australia', ${ }^{160}$ and our analysis reveals a marked unevenness in protection for alleged victims both across and within jurisdictions. The lack of consistency in approach and lack of uniformity in provisions across the jurisdictions means that not all victims of domestic and family violence are protected, and for those who are, the nature and extent of those protections differ. Indeed, alleged victims of domestic and family violence are particularly disadvantaged in NSW where they lack protection from direct cross-examination in any matters involving domestic and family violence other than sexual assault offences.

Our analysis also reveals the lack of guidance for judicial decision-making in cases where the protections are either discretionary or can be waived by consent.

160 Australasian Institute of Judicial Administration, National Domestic and Family Violence Bench Book (2018) <http://dfvbenchbook.aija.org.au/purpose-and-limitations/>. 
A particular concern in this context is that variable levels of judicial knowledge and awareness of the nature of domestic and family violence will greatly disadvantage victims and generate unsafe outcomes in many cases. In the absence of research and inquiry though, we know little as to how these provisions have been operationalised and in particular, issues of consistency and effectiveness of application.

There is a critical need for research which examines how these provisions operate in practice. As has been noted in the context of research which examined civil protection order legislation in Australia: 'whether the written intentions translate into practice is another question' ${ }^{161}$ The analysis presented in this article relies on the law as written. This has enabled us to provide a comparison of legislation across proceedings and jurisdictions. This can provide an indication of the values 'embodied in current statutory language' 162 and has drawn attention to the fact that NSW is out of step with other states and territories in providing protection from personal cross-examination in cases involving domestic and family violence in criminal and civil protection order proceedings. It has also drawn attention to variation across the jurisdictions in terms of whether the protections that can be invoked are mandatory or discretionary, whether the intermediary must have legal qualifications, and whether a 'sliding scale' in terms of criminal versus civil proceedings is evident in terms of the way the protection is articulated and invoked. This analysis of the 'law as written' does not however enable a discussion about whether any differences between jurisdictional approaches makes a difference in terms of practice, nor whether and how such protections assist victims of domestic and family violence to give their best evidence in relevant proceedings. Qualitative analyses and comparisons are required, including how these provisions interact with other protective provisions that might be utilised to assist alleged victims in giving their evidence in court (such as pre-recorded evidence, audio-visual links, and screens). In this regard it is of interest to note that the federal act preventing cross-examination in family law proceedings includes a provision that requires it to be 'reviewed' two years after commencement. ${ }^{163}$ The review is to include a cost analysis of providing legal representation. ${ }^{164}$ It is to be hoped that the review will be more than a cost-analysis and will be a full evaluation of the experiences of victims, perpetrators, legal professionals and judicial officers.

161 Samantha Jeffries, Christine EW Bond and Rachael Field, 'Australian Domestic Violence Protection Order Legislation: A Comparative Quantitative Content Analysis of Victim Safety Provisions’ (2013) 25(2) Current Issues in Criminal Justice 627, 640.

162 Ibid 635.

163 Family Law Amendment (Family Violence and Cross-Examination of Parties) Act 2018 (Cth) sch 1 item 102NC.

164 O’Dwyer and Porter (n 13). 